\title{
Associations between elevated atmospheric temperature and human mortality: a critical review of the literature
}

Article

Accepted Version

Gosling, S. N., Lowe, J. A., McGregor, G. R., Pelling, M. and Malamud, B. D. (2009) Associations between elevated atmospheric temperature and human mortality: a critical review of the literature. Climatic Change, 92 (3-4). pp. 299341. ISSN 0165-0009 doi: https://doi.org/10.1007/s10584-0089441-x Available at https://centaur.reading.ac.uk/5958/

It is advisable to refer to the publisher's version if you intend to cite from the work. See Guidance on citing.

Published version at: http://dx.doi.org/10.1007/s10584-008-9441-x

To link to this article DOI: http://dx.doi.org/10.1007/s10584-008-9441-x

Publisher: Springer Netherlands

Publisher statement: The original publication is available at www.springerlink.com

All outputs in CentAUR are protected by Intellectual Property Rights law, including copyright law. Copyright and IPR is retained by the creators or other copyright holders. Terms and conditions for use of this material are defined in the End User Agreement.

www.reading.ac.uk/centaur 
Central Archive at the University of Reading

Reading's research outputs online 
Simon N. Gosling ${ }^{1}$, Jason A. Lowe ${ }^{2}$, Glenn R. McGregor ${ }^{3}$, Mark Pelling ${ }^{1}$, Bruce D. Malamud ${ }^{1}$

${ }^{1}$ King's College London, Department of Geography, London, UK.

${ }^{2}$ The Met Office Hadley Centre, Exeter, UK.

${ }^{3}$ King's College London, Department of Geography, London, UK; and The University of Auckland, School of Geography, Geology and Environmental Science, Auckland, New Zealand.

\title{
Address for correspondence:
}

Mr Simon Gosling,

King's College London,

Department of Geography,

Strand,

London WC2R 2LS,

United Kingdom.

Tel. +44(0)207848 2599

Email. simon.gosling@kcl.ac.uk

\begin{abstract}
The effects of the anomalously warm European summer of 2003 highlighted the importance of understanding the relationship between elevated atmospheric temperature and human mortality. This review is an extension of the brief evidence examining this relationship provided in the IPCC's Assessment Reports. A comprehensive and critical review of the literature is presented, which highlights avenues for further research, and the respective merits and limitations of the methods used to analyse the relationships. In contrast to previous reviews that concentrate on the epidemiological evidence, this review acknowledges the inter-disciplinary nature of the topic and examines the evidence presented in epidemiological, environmental health, and climatological journals. As such, present temperature-mortality relationships are reviewed, followed by a discussion of how these are likely to change under climate change scenarios. The importance of uncertainty, and methods to include it in future work, are also considered.
\end{abstract}

\section{KEY WORDS}

Temperature Mortality Climate Change Health Heat Wave Review Projections Uncertainty 


\section{INTRODUCTION}

Morbidity and mortality incidence rates are seasonal and have long been associated with the effects of both heat and cold (Sakamoto-Momiyama, 1977; Ellis, 1978; McKee, 1989). However, as recently as the late 1980s and early 1990s, the associated risks that global climate change poses to health received little attention in the published literature (WHO, 2003), as evident in the limited reference made to it in the First Intergovernmental Panel on Climate Change Report (IPCC, 1990). Since then, research by epidemiologists and climatologists has grown rapidly, using a range of methods to analyse climate-health relationships. This development is reflected in the IPCC Third Assessment Report (IPCC, 2001) where an entire chapter is reserved for human health. However, only a brief section is devoted to the direct impacts of thermal stress (heat waves and cold spells), and this is also the case with the Fourth Report (IPCC, 2007a).

An indicative list of heat wave impacts for the period 2000-2007 is presented in Table 1 (EM-DAT, 2007). France was one of the most severely affected countries in the European August 2003 heat wave. Table 1 illustrates that there were vastly fewer deaths in France during the 2006 heat wave, perhaps due to a reduction in heat wave intensity and a heat health watch warning system (French Institute for Public Health Surveillance, 2006; Pascal et al., 2006). However, Table 1 illustrates that the 2006 heat wave was associated with similar or more deaths than the 2003 event in The Netherlands and Belgium respectively (EM-DAT, 2007). This highlights the importance of studies examining the association between elevated temperature and mortality, and the need to build on the coverage received in the IPCC Assessment Reports (IPCC, 2001 and 2007a) with an up-todate review of the literature concerned.

This review differs from previous works that have focussed purely on epidemiological studies (Basu and Samet, 2002). Such epidemiological studies seek to investigate and quantify the various risk factors that affect temperature-related mortality. These factors may include air pollution and socioeconomic status for example. Here a more holistic approach has been adopted because we also include studies where the focus is shifted away from understanding the various mortality risk factors, towards a focus on describing the relationship between atmospheric temperature and other meteorological variables and mortality, and how this relationship may be affected by climate change. This approach highlights the inter-disciplinary nature of the topic. The first section examines present temperature-mortality relationships as examined by epidemiological and synoptic climatological methods, while the second section discusses climate change issues and examines the impacts of climate change on heat-related mortality. A unique element of the 
review is the critical appraisal of methodological issues, which precedes a presentation of the main research findings. Further research needs are highlighted throughout.

\section{REVIEW OF PRESENT TEMPERATURE-MORTALITY RELATIONSHIPS}

\subsection{Methodological Approaches and Related Issues}

\subsubsection{Calculation of excess mortality}

The majority of temperature-mortality studies do not use raw mortality data, but in order to give an indication of the mortality attributable to temperature, calculate an excess mortality that is estimated by subtracting the expected mortality from the observed mortality. The expected mortality is often called the baseline mortality. Numerous methods have been identified in the literature for calculating the expected mortality, largely dependent upon the chosen baseline. These, and their respective advantages and disadvantages are summarised in Table 2. As a result of these differences, mortality estimates are sensitive to the methods used (WHO Regional Committee for Europe, 2003). This sensitivity is a source of uncertainty in the temperature-mortality relationships derived and makes comparisons between studies less reliable. For example, studies that calculate excess mortality above a baseline mortality rate (e.g. Gosling et al., 2007) are likely to provide lower estimates of mortality than other studies that use mortality rates directly (e.g. Conti et al., 2005). In this situation, the two mortality rates, and likewise any temperature-mortality relationships, derived from these studies would not be directly comparable. This uncertainty is rarely accounted for. However, in a study of the Chicago 1995 heat wave Whitman et al. (1997) calculated different estimates of expected mortality from three different regression analyses. In another study, Dessai (2002) observed that temperaturemortality estimates were either over- or under-represented depending on the specific baseline used. Dessai (2002) demonstrated that at $43^{\circ} \mathrm{C}$, mortality was $20 \%$ higher when using a 30-day running mean baseline compared with a fixed mean of daily mortality for each month in previous years. Dessai's (2003) exploratory Bayesian analysis demonstrated future heat-related mortality predictions were less sensitive to baseline methods than the knowledge of uncertainties of climate change and human acclimatisation. However this does not rule out the necessity to standardise the method of calculating excess mortality and/or accounting for the associated uncertainties in future studies.

An additional source of uncertainty, although relatively minor compared with the choice of mortality baseline, arises from the way that deaths are classified in the selected daily mortality time series. Some studies use mortality data that has been classified 
according to the World Health Organisation (WHO) Ninth International Classification of Diseases (ICD 9; WHO, 1980). For example, some studies include deaths from all causes other than external causes such as accidents and violence (Kan et al., 2007; Knowlton et al., 2007; Hajat et al., 2002). This corresponds to all ICD 9 codes less than 800. Other studies use mortality from “all causes” (Gosling et al. 2007; Pascal et al. 2006; Pattenden et al. 2003) or non accidental deaths (Kassomenos et al., 2007). Less common is the use of deaths certified as being "heat-related" (Whitman et al. 1997).

In a long time-series, the changing age-structure of the population should be accounted for, because an ageing population will be more vulnerable and may bias temporal comparisons (Calado et al., 2005; Davis et al., 2003a). This is commonly achieved by the direct standardisation method (Anderson and Rosenberg, 1998), or by only examining a restricted age group. This method is commonly applied in the epidemiological and synoptic climatological approaches. However, detailed and extensive datasets of daily mortality data stratified by age group are required for this, which is why a number of temperature-mortality assessments have not incorporated this standardisation method (Gosling et al., 2007; Casimiro et al., 2006; Dessai, 2002).

\subsubsection{The epidemiological approach}

The epidemiological approach involves explaining an outcome measure (e.g. mortality) based upon a predictor(s) (e.g. temperature) and potentially confounding variables such as season, air pollution, other meteorological variables, and socio-economic status (Basu and Samet, 2002). This can broadly be achieved by two main methods, (1) the analysis of time series data by Poisson regression and generalised additive models (GAMs), and (2) caseonly or case-crossover studies. The principal difference between the epidemiological approach and others such as the synoptic climatological approach is the consideration and modelling of various confounding factors in the former.

Poisson regression and GAMs relate the log-expected death count to the predictor(s) and confounders (Páldy et al., 2005; O’Neill et al., 2003; Pattenden et al., 2003; Curriero et al., 2002; Hajat et al., 2002). Daily temperature can be represented by linear or non-linear terms in the models, on the same day or as lagged days (Braga et al., 2001; Schwartz and Dockery, 1992). Additional terms may be added to the model to control for the confounding factors. This represents a major difference between the epidemiological and the synoptic climatological approach because in the latter, the weather is not parameterised (Samet et al., 1998). A summary of studies that attempt to explain mortality as a function of temperature and other meteorological and environmental 
variables is presented in Table 3. In some cases, socio-economic and/or lifestyle variables are also included; see Table 4.

Tables 3 and 4 illustrate that temperature is usually represented in terms of minimum, maximum or mean daily temperature. However, very little attention is paid to the explicit role of the diurnal temperature range (DTR). A recent exception is provided by Kan et al. (2007), who hypothesised that large diurnal temperature change might be a source of additional environmental stress, and therefore a risk factor for death. The 4-year study demonstrated significant increases in total mortality associated with increases in daily DTR, independent of the corresponding temperature level, in Shanghai on warm and cold days. The study acknowledges that temperature level may modify the effect of DTR on mortality differently depending on different weather patterns. Chen et al. (2007) made similar observations for stroke deaths in Shanghai. This novel risk factor deserves further research, especially as reductions in the DTR are projected with climate change (Meehl et al., 2007). The DTR is often included as a variable in the synoptic climatological approach, as discussed in the next section. Other studies calculate biometeorological indices such as the apparent temperature (Hajat et al., 2006; Michelozzi et al., 2005; Davis et al., 2003; Smoyer et al., 2000a) or humidex (Conti et al., 2005). These indices are absolute so that they assume the weather has the same impact on the human body regardless of location or the time at which it occurs. Therefore there has been recent interest in the computation of relative biometeorological indices such as the heat stress index (Watts and Kalkstein, 2004) that is based on apparent temperature, cloud cover, and consecutive days, and HeRATE (Health Related Assessment of the Thermal Environment) that combines a physiologically relevant assessment procedure of the thermal environment with a conceptual model to describe short-term adaptation (including short-term acclimatisation and behavioural adaptation) to the thermal conditions of the past four weeks (Koppe and Jendritzky, 2005). Other studies prefer only to examine temperature-mortality associations above a specific threshold (e.g. the $95^{\text {th }}$ percentile of daily temperature; Gosling et al. 2007; Hajat et al. 2002) - this is discussed in more detail in Section 2.1.4.

The epidemiological approach can be applied to isolated events such as heat waves (Calado et al., 2005; Conti et al., 2005; Michelozzi et al., 2005; Smoyer, 1998) or over longer periods that use time-series data (Hajat et al., 2006 and 2005; Pattenden et al., 2003; Dessai, 2002; Gemmell et al., 2000; Danet et al., 1999; Ballester et al., 1997). Although the analysis of isolated heat waves provides a useful insight into the short-term response of the population to the event, they can overestimate the effect of temperature due to shortterm mortality displacements (Sartor et al., 1995) and inappropriate use of mortality baselines (Rooney et al., 1998; Whitman et al., 1997). An increasingly popular and more 
objective method to examine the temperature-mortality association is to investigate longperiod time-series data through regression analysis, and then identify individual events such as heat waves in that time-series for further analysis (Páldy et al., 2005; Hajat et al., 2002; Huynen et al., 2001).

There are limitations in including environmental variables under the epidemiological approach. Firstly, a single weather element may not be representative of the total effect of weather on health because other meteorological variables can affect human health synergistically (Kalkstein, 1991). However, there is some evidence that individual elements such as humidity have no significant relationship with mortality (Dessai, 2002, 2003; Ballester et al., 1997; Braga et al., 2001). Secondly, measurements of meteorological variables are often obtained from point-source weather stations that may be some distance from where the health effects are recorded, and more importantly, may not be representative of the conditions within the buildings where most deaths occur (Kilbourne, 1997). Thirdly, it is possible that mortality variation is pollution-orientated (Kalkstein, 1991), but the inclusion of individual pollutant variables and weather variables as additive independent variables is unjustified because of the possibility of collinearity between the two (Roberts, 2004; Sartor et al., 1995). Nevertheless, the degree to which air pollution effects mortality deserves further research, since attribution to this is uncertain (Kan et al., 2007; Pattenden et al., 2003; Hajat et al., 2002; Keatinge and Donaldson, 2001; Smoyer at al. 2000b). The problem of collinearity may also arise when including nonenvironmental variables in temperature-mortality regression models. For example, Chesnut et al. (1998) observed a statistically significant negative relationship between percentage of the population that graduated from high school and hot-weather-related mortality. It should be noted that the relationship is not necessarily causal, and may be explained due to the correlation between high school graduation and income, such that wealthier populations can take more preventative action against adverse conditions (e.g. air conditioning) (Semenza et al., 1996). Hence regression coefficients for one variable may be a reflection of the influence of any other correlated variable, so results should be treated with caution. It is perhaps due to this limitation that there is a marked variation in the degree to which socio-economic factors and/or lifestyle variables are related to heat-related mortality (Michelozzi et al., 2005; Guest et al., 1999). Compounding this limitation is the use of different indicators of socio-economic status, which impedes cross-study comparisons.

The case-only or case-crossover epidemiological approach allows examination of the relationship between an acute event and a quick-changing risk factor by including only people that experience the acute event in the analysis (Maclure, 1991). Basu and Samet (2002) describe the approach as being where two or more time periods are defined for each 
person experiencing the outcome. One of these is the "hazard period" that represents the exposure period to the acute event. The other period consists of one or more "control periods" that represent the exposure experienced before and/or after the hazard period. However, this means that the date of death for each individual is required - something that is not always available (Basu, 2001). Armstrong (2003) has noted how this method can be used to examine the acute effects of weather, such that the limitation of socio-economic variable-collinearity in GAMs can to some extent be resolved because complex modelling of confounders is not required. This is mainly because the individuals under examination also act as their own control; i.e. before and after the acute event (Schwartz, 2005; Semenza et al., 1996; Kilbourne et al., 1982). This approach is therefore useful for future studies, but they must account for two important factors: firstly the Neyman bias (Redelmeier and Tibshirani, 1997): a circumstance in which deaths occur due to more severe causes, but are not attributed to heat stress (the outcome of interest), and secondly, a need to control for seasonal interactions that could have implications for how reliable temperature-susceptibility measures are (Armstrong, 2003). It should be noted that although this approach is useful for monitoring at-risk groups, preventative measures should be aimed at the population as a whole, as well as particularly vulnerable groups (Ballester et al., 1997).

\subsubsection{The synoptic climatological approach}

The limitations associated with environmental variables under the epidemiological approach can to some extent, be alleviated by adopting a synoptic climatological approach. This uses principal components analysis (PCA) and cluster analysis (CA) to group daily homogenous meteorological variables in to air mass groups. The result is a temporal synoptic index (TSI) that can be compared with daily mortality (Kalkstein, 1991; Kalkstein and Smoyer, 1993; Greene and Kalkstein, 1996; Chesnut et al., 1998; Guest et al., 1999; Kassomenos et al., 2007). However, a limitation of the TSI is that it is location-specific. Air masses are defined without regard to other places, meaning the 'oppressive' air mass groups identified for one region may be different to those for another, which renders regional comparisons problematic. This problem has been overcome by applying a methodology that identifies the major air masses traversing a particular region, to produce a spatial synoptic classification (SSC) (Kalkstein and Greene, 1997; Sheridan and Kalkstein, 2004). This has been refined as the SSC2 for use across North America (Sheridan, 2002). However, Guest et al. (1999) argue that it is always possible that TSI- or SSC-mortality associations may arise partly from confounding factors. 
McMichael et al. (1996) have illustrated the usefulness of the TSI in climate-health research and Guest et al. (1999) concluded the TSI was the most comprehensive method for examining climate-mortality relationships in Australia over the period 1979-1990, compared with the epidemiological approach of non-linear regression and correlation analyses. However, Samet et al. (1998) compared the TSI approach with linear- and nonlinear regression methods, concluding that the inclusion of parametric or smoothed terms to control for the weather in Philadelphia during the period 1973-1980 were superior. Nevertheless the practical benefits of the synoptic approach have been realised through the development of numerous heat health watch warning systems in cities such as Shanghai, Toronto, Rome, and Chicago (Sheridan and Kalkstein, 2004). Until recently, the synoptic climatological approach has rarely been adopted outside of the US, but McGregor (1999) has applied the methodology to examine winter ischaemic heart disease in Birmingham (UK) and Kassomenos et al. (2007) have examined heat stress in Athens (Greece). Also, Bower et al. (2007) have developed a new SSC for Western Europe (SSCWE) based on data from 48 weather stations over the period 1974-2000. Similar studies in Europe and the developing world would advance the climate-health knowledge base.

\subsubsection{Defining heat waves}

A major issue of debate is how "hot days" or heat waves should be defined. Robinson (2001) defines a heat wave as "an extended period of unusually high atmosphere-related heat stress, which causes temporary modifications in lifestyle, and which may have adverse health consequences for the affected population." Therefore although heat waves are meteorological events, they are more usefully defined with reference to human impacts. Considering this, Robinson (2001) accounts for intensity and duration and proposes heat waves in the US should be defined as periods of at least 2 days when absolute thresholds of daytime high and nighttime low apparent temperature are exceeded. A similar definition is adopted by the Netherlands Royal Meteorological Institute, which defines a heat wave as a period of at least 5 days, each of which has a maximum temperature of $25^{\circ} \mathrm{C}$ or higher, including at least 3 days with a maximum temperature of $30^{\circ} \mathrm{C}$ or higher (Huynen et al., 2001). Tan et al. (2007) defined hot days in Shanghai as when the daily maximum temperature exceeded $35^{\circ} \mathrm{C}$, to correspond with the Chinese Meteorological Administration heat warnings that are issued when maximum temperatures are forecast to exceed $35^{\circ} \mathrm{C}$.

However, absolute thresholds such as these cannot be applied directly elsewhere because the sensitivity of populations to heat will vary spatially. For example, in cooler regions the thresholds may never be reached, and the thresholds may have to be higher in hotter regions to ensure only those events perceived as stressful are identified. The UK Met 
Office's Heat-Health Watch system (Department of Health, 2007) deals with this by issuing health alerts based upon whether threshold maximum daytime and minimum nighttime temperatures, which vary by region, are reached on at least two consecutive days and the intervening night. For example the thresholds for London are $32^{\circ} \mathrm{C}$ (day) and $18^{\circ} \mathrm{C}$ (night) but the thresholds for North East England are $28^{\circ} \mathrm{C}$ (day) and $15^{\circ} \mathrm{C}$ (night).

These spatial differences are accounted for elsewhere by defining the intensity by using temperature percentiles. Bensiton (2004) defines heat waves as 3 successive days when the temperature exceeds the $90^{\text {th }}$ percentile of summer maximum temperature, because this corresponds to the extreme high tail of probability density function of maximum summer temperature as defined by the IPCC (2001). Hajat et al. (2002) defined heat waves as periods of 5 consecutive days or longer when a smoothed 3-day moving average of temperature exceeded the $97^{\text {th }}$ centile of average temperature for the entire period. Gosling et al. (2007) defined heat waves as periods lasting three or more consecutive days when the daily maximum temperature was equal to, or greater than, the 95th percentile of summer maximum temperature over the whole period of record. Although the use of percentiles in this manner allows for regional differences in sensitivity, it does not account for seasonal changes in the sensitivity. Furthermore it remains possible that in some very cool locations with little temperature variability, a threshold such as the $99^{\text {th }}$ percentile may produce no appreciable increase in mortality. Regarding the duration, it is rarely justified why the chosen percentile should be exceeded for how ever many days. The importance of the duration of stressful weather conditions has been highlighted by studies adopting a synoptic climatological approach. Sheridan and Kalkstein (2004) have demonstrated for Toronto that although increases in mortality may be statistically significant on the first day of an oppressive weather type (dry tropical), they may increase up to tenfold if the offensive weather type persists for five consecutive days. Furthermore, Kyselý (2007) has demonstrated that surface air temperature anomalies over Europe are linked to the persistence of certain circulation patterns over Europe, and that the occurrence and severity of temperature extremes (heat and cold) become more pronounced under a more persistent circulation. The longer continuous exposure to oppressive weather places additional stress upon the human body. A heat wave definition that considers the TSI/SSC methodology would therefore be useful. Although a common, formal definition of a heat wave for a wide area such as Europe is desirable, it is the limitations discussed here that hinder its formulation, and is perhaps why no common, formal definition of a heat wave currently exists (Koppe et al., 2004). 


\subsection{Findings}

Both warm and cold extremes of temperature have adverse effects on health, such that a non-monotonic relationship is often observed between temperature and mortality, with a temperature band of minimum mortality. This band is sometimes referred to as the 'comfort range' (Martens, 1998), the limits of which represent the 'threshold temperature'. Beyond this mortality increases above the baseline level (Kalkstein and Davis, 1989). A summary of observed threshold temperatures is presented in Table 5, which also highlights that different thresholds have been identified for different causes of death. Furthermore, threshold values may be confounded by other meteorological variables - for example, Saez et al. (2000) illustrated a $2^{\circ} \mathrm{C}$ higher threshold $\left(23^{\circ} \mathrm{C}\right)$ on very humid days (when the relative humidity was above $85 \%$ ) compared to less humid days in Barcelona, Spain. This is interesting because a lower threshold temperature might be expected with higher humidity because high humidity increases heat stress by hindering the evaporation of sweat (Donaldson et al. 2003). Days when the relative humidity was above $85 \%$ represented only $2 \%$ of all days in the time series, however. Thresholds can also vary according to age, with elderly populations being most susceptible to changes in temperature (Hajat et al., 2007; Conti et al., 2005; Empereur-Bissonnet, 2004; Donaldson et al., 2003; Huynen et al., 2001; Danet et al., 1999; Whitman et al., 1997), and temporally for a single location (Davis et al., 2003a; Ballester et al., 1997). Comparative studies have shown thresholds for heatrelated/cold-related mortality occur at higher/lower temperatures in locations with a relatively warmer/colder climate, and the gradient (or steepness) of the temperaturemortality relationship for increasing/decreasing temperature is often found to be lower in warmer/colder locations than colder/warmer ones (Donaldson et al., 2003; Pattenden et al., 2003; Keatinge et al., 2000; Eurowinter 1997). These patterns are evident on global and regional scales and may generally be observed in Table 5. At the regional scale, Laaidi et al. (2006) illustrated a higher threshold in Paris than in Côte-d'Or and The Hautes-Alpes in France. Warmer temperatures associated with Paris's urban heat island (Oke, 1987) were considered as an explanation. Some evidence suggests that urban populations are more susceptible to extreme heat events (Smoyer et al., 2000a) and the benefits of urban green spaces have been highlighted by Tan et al. (2007). These findings support the conclusions of McGeehin and Mirabelli (2001) that urban heat islands elevate personal mortality risk. However, Sheridan and Dolney (2003) observed no statistically significant relationship between daily mortality and the level of urbanization for Ohio for 1975-1998. It should also be noted that the additional influence of pollution in urban areas is a possible compounding reason for observations that show urban areas have elevated mortality risk. For example, 
based upon nine French cities, Filleul et al. (2006) confirmed that in urban areas ozone levels have a non-negligible impact in terms of public health.

The existence of threshold temperatures mean ' $U-$ ' or 'V-shaped' temperaturemortality relationships are common (Laaidi et al., 2006; Páldy et al., 2005; Pattenden et al., 2003; Huynen et al., 2001; Ballester et al., 1997), and in some cases a 'J-shape' relationship is observed due to much higher excess mortality in colder or warmer conditions due to acclimatisation to one or the other (Donaldson et al., 2003; Braga et al., 2001; Saez et al., 2000; Pan et al., 1995). For example, Curriero et al. (2002) observed 'Jrelationships' for southern US cities with a warm climate and 'U-relationships' for cooler northern cities. The variation of threshold values and temperature-mortality gradients has led to inference on how populations may acclimatise to changing climatic conditions (discussed later).

The treatment of the relative timing of extreme temperature and mortality has been found to have an impact on study results. In particular mortality variance may be impacted by lag effects, "mortality displacement", time in the year that extreme temperatures occur, and the number of extreme days in sequence. Extreme temperatures can have direct effects on health but the impacts are not always immediate. A lag is often observed between the temperature event and resultant mortality whereby separate previous days' temperatures (Conti et al., 2005; Hajat et al., 2002) or lagged moving averages (O'Neill et al., 2003; Pattenden et al., 2003; Saldiva et al., 1995) are associated with the current day's mortality. Table 6 presents a summary of studies examining the prevalence of lag effects. Various methods have been used to analyse lags, including distributed lag models and Poisson regression techniques (Hajat et al., 2005; O’Neill et al., 2003; Dessai, 2002; Braga et al., 2001; Schwartz, 2000), and graphical methods combined with mortality changes perdegree-change in temperature (Pattenden et al., 2003; Hajat et al., 2002; Whitman et al., 1997). Table 6 illustrates that lags of less than 3 days are most commonly associated with heat-related total mortality. Different lag periods may be associated with disease-specific mortalities (Ballester et al., 1997) and locations (Conti et al., 2005; Pattenden et al., 2003). Despite the wealth of studies including a lag effect in the analysis, Braga et al., (2001) argue that there is little systematic examination of them, and a limitation is that choices of lags are often made a priori rather than on biological plausibility.

Some studies have shown a negative relationship between hot temperatures and mortality for lags around 3 days (Hajat et al., 2006 and 2005; Pattenden et al., 2003; Hajat et al., 2002; Braga et al., 2001; Kunst et al., 1993), and even for lags of 7-30 days (Gosling et al., 2007; Le Tertre et al., 2006; Huynen et al., 2001; Sartor et al., 1995). This phenomenon has been attributed to "mortality displacement", whereby the heat principally 
affects individuals whose health is already compromised and who would have died shortly anyway, regardless of the weather. Estimates of mortality displacement are often calculated for defined heat wave periods that include "before", "during" and "after" the heat wave periods, lasting typically less than 2 months (Gosling et al. 2007; Le Tertre et al. 2006; Sartor et al. 1995). The effect of mortality displacement is usually calculated by dividing the mortality deficit (the number of "negative excess deaths" after the heat wave i.e. the number of deaths below that expected after the heat wave) by the total number of excess deaths during the heat wave (i.e. deaths above that expected during the heat wave) and converting to a percentage. Estimates of mortality displacement calculated by this method include 15\% during the Belgium 1994 heat waves (Sartor et al., 1995), 50\% during the 1994 Czech Republic heat wave (Kyselý and Huth, 2004), 6\% and 30\% in Paris and Lille respectively during the 2003 European heat wave in France (Le Tertre et al. 2006), and 71\% 45\% and 59\% in Budapest, London and Sydney during heat waves in 1991, 2003 and 2004 respectively (Gosling et al. 2007).

It should be noted that estimates of mortality displacement and lag differences may be sensitive to the ways in which deaths are attributed to a particular date. Some studies use mortality counts where the date of death is the "date the death occurred" (e.g. Johnson et al. 2005; Huynen et al., 2001; Kalkstein and Davis, 1989). However, others use the "date the body was found" (e.g. Naughton et al., 2002) so some of the deaths recorded on these dates likely occurred earlier. The degree of, and occurrence of mortality displacement appears to be location specific and related to demographic, social, and health profiles meaning that occurrence and attribution varies greatly (Gosling et al., 2007; Le Tertre et al., 2006; Hajat et al., 2005; Pattenden et al., 2003; Braga et al., 2001). For example, a reanalysis of the Chicago (US) 1995 heat wave by Kaiser et al. (2007) highlighted that the risk of heatrelated deaths was significantly higher among African Americans, and mortality displacement was disproportionably and substantially lower among this group. This is likely to be related to socioeconomic status - Krieger et al. (1997) have suggested that African Americans are more likely than White Americans to live in impoverished neighbourhoods, even if they have similar incomes. Regarding methodological approaches, Pattenden et al. (2003) have noted that if using lagged moving averages of temperature where mortality displacement is evident, utilisation of short meaning periods (around 2 days) may produce mortality overestimates, implying longer meaning periods are appropriate.

Few studies have examined mortality with reference to the time in the year when the temperatures occur. Kalkstein (1990) notes some evidence for hot-weather-related mortality being greater during early summer heat waves than during later ones. In support, 
Rooney et al. (1998) observed that although warmer, the peak mortality during the 1995 UK heat wave was less than it was for the 1976 heat wave which occurred relatively earlier in the summer than the 1995 event. Similarly, Páldy et al. (2005) illustrated that the first heat wave in a year has a greater mortality-impact than the second, regardless of temperature magnitude and event duration in Budapest, based on 31 years of data. Also, Hajat et al. (2002) discovered that despite having higher mean temperatures, mortality increased by only $3.26 \% /{ }^{\circ} \mathrm{C}$ for July-August hot days but by $5.39 \% /{ }^{\circ} \mathrm{C}$ for all other hot days in the 'cooler' months of the year in London for the period 1976-1996. These findings are attributed to mortality displacement or behavioural and/or physiological acclimatisation that allows people to deal more effectively with heat waves later in the season (Kalkstein, 1990). In contrast, Tan et al. (2007) observed late-season heat waves in Shanghai were more deadly than those occurring in the early season, although the statistical significance of this result is likely due to the analysis being based on only two years: 1998 and 2003.

Accounting for the number of consecutively warm days is also less common in the literature. Hajat et al. (2002) identified 11 hot periods between 1976 and 1996 in London that generally showed the largest rises in mortality were observed in those periods of longest duration or where the temperatures were at their highest. An analysis of heat waves in the Netherlands over the period 1979-1997 by Huynen et al. (2001) demonstrated that the longest lasting heat wave over this period; 13 days, was associated with the highest excess mortality recorded. Smoyer (1998) analysed 4 summer heat waves in St Louis, US and discovered the highest mortality occurred in a heat wave in 1980, which was the hottest, longest in duration, and earliest in seasonal onset of the four. Also in St. Louis, Kalkstein (1991) used multiple regression to show that a 'heat wave duration' variable explained the most variance in mortality, suggesting that high temperature duration was more important than any meteorological factor. Analysis of heat waves occurring in 1998 and 2003 in Shanghai by Tan et al. (2007) has demonstrated that prolonged exposure to heat is more stressful to human health than isolated hot days. These findings are explained by the cumulative effect of heat on the body's ability to regulate temperature, which puts a strain on the thermoregulatory system (Semenza et al., 1996; Braga et al., 2001).

Inclusion of air-conditioning use in GAMs is common and there is much evidence that it serves to decrease summer mortality rates but the conclusions are based on findings solely for US cities (Davis et al., 2003a; Donaldson et al., 2003; Curriero et al., 2002; Braga et al., 2001) and the magnitudes of the decrease vary. For example, Kalkstein (1993) calculated a $21 \%$ reduction in mortality due to air-conditioning use in New York. Davis et al., (2003) have calculated a reduction of 1.14 deaths/year for every $1 \%$ increase in air- 
conditioning availability for several US cities. Furthermore, Barnett's (2007) casecrossover study concluded that cardiovascular mortality risk since 1987 across 107 US cities had disappeared by 2000 , probably due to air-conditioning use. Such findings lead to the conclusion that air-conditioning will alleviate some of the increase in excess mortality due to climate change, but as some cities are already close to air-conditioning saturation (100\% household usage) (Kalkstein and Greene, 1997), there is a need to estimate how such locations will fare under more extreme temperatures in the future. Likewise, an area for further research is the benefits that may arise from future air-conditioning installations in European cities. However, care should be taken not to consider air-conditioning as an appropriate adaptive response because it can be perceived as mal-adaptation. Furthermore, additional heat would be released by air-conditioning units. Although internal temperatures may be kept below health-related thresholds, outside temperatures would likely be made worse by expansion of air conditioning. Compounding this is that air-conditioning is currently affordable by only a few, thus increasing the inequity between the economically advantaged and disadvantaged (McGregor et al., 2006). However, in some future estimates of global and regional wealth and technological development (Nakićenović and Swart, 2000) air conditioning may become affordable to a greater fraction of the world's population in the future. Capabilities of regional power grids would have to improve in such circumstances to deal with the extra load created by increased air-conditioning usage. Power grid failures have become more common in the US during heat wave events, for example July 2006 in California and July 1995 in Chicago when 49,000 households were left with no electricity (Klinenberg, 2002).

\section{REVIEW OF PREDICTIONS OF TEMPERATURE-MORTALITY RELATIONSHIPS UNDER CLIMATE CHANGE SCENARIOS}

Future climate change is considered by many to be one of the most serious threats to both human life and current lifestyles (IPCC, 2007a). Recent assessments of the dangers of climate change, without significant mitigation and/or adaptation, suggest the potential impacts during the $21^{\text {st }}$ century on health, water resources, food availability and economic development are likely to be immense (Schellnhuber et al., 2006). In this review we report on both changes in the recent past that may be linked to climate change and on existing projections of future health impacts. We conclude by discussing how uncertainties in these projections might be quantified. 


\subsection{Recent changes in climate and its health impacts}

Consideration of past climate change focuses on two main questions. Has the climate changed? And is the cause wholly or partially manmade? During the $20^{\text {th }}$ century the global average surface temperature increased by around $0.74^{\circ} \mathrm{C}$, making the last 10 years the warmest decade in the instrument record and probably the warmest during the past 1,300 years (IPCC, 2007b). It is not only the yearly averages of temperature that have altered, extremes of temperature also appear to have changed (IPCC, 2007b). In some locations the extremes have changed by different amounts than the yearly averages.

Numerous attribution studies have linked the warming over recent changes to human driven emissions of greenhouse gases (Hegerl et al., 2006; Ingram, 2006; Jones et al., 2005). What is also clear from these studies is that it is more difficult to detect a human signal on smaller spatial scales, and in situations where natural variations tend to be very large. This has hindered the formal attribution of many impacts quantities. Despite this difficultly it is still useful to examine changes in health impacts over time, and to establish whether the behaviour is consistent with that expected from measured regional climate changes. For example, in Athens, Greece, for the period 1966-1995, McGregor et al. (2002) have illustrated a tendency towards an increase in the length of the discomfort season. Health authorities have responded to these predictions and previous extreme events by implementing early warning and intervention systems, in locations including Shanghai (Tan et al., 2004), Philadelphia (Kalkstein et al., 1996), Portugal (Calado et al., 2005), Italy (de' Donato et al., 2006), England (Department of Health, 2007) and France (Michelon et al., 2005). It should also be noted that the increased frequency of extreme heat events is likely to be accompanied by a reduction in the frequency of extreme cold events. For example, in a warmer climate associated with the SRES A1B scenario, Vavrus et al. (2006) report a 50 to $100 \%$ decline, compared to present, in the frequency of cold air outbreaks in the Northern Hemisphere winter for most areas. Projections such as this has led to inference that warmer winters will result in reduced cold-related mortality, and that this may offset increases in heat-related mortality (discussed later).

An alternative approach to the climate detection and attribution studies referred to above was performed by Stott et al. (2004). Rather than needing an evolving history of events this technique can be used to estimate the difference in likelihood of a given heatwave event in a climate with manmade climate change, compared to an idealised situation in which pre industrial conditions persisted to present day. The study concludes that it is very likely that human influence has at least doubled the risk of a heatwave exceeding the temperatures evident in 2003 in Europe. 


\subsection{Future climate and heat waves}

Even if the atmospheric concentrations of greenhouse gases in the atmosphere were stabilised today, the temperature would continue to rise due to the unrealised effect of past climate forcing increases (Meehl et al., 2005). Future increases in greenhouse gas concentrations, from future emissions, will add to the committed warming thus leading to even higher temperatures. The spatial pattern of surface atmospheric temperature change will not be uniform, with air over land warming more than over the ocean, enhanced warming at high northern latitudes, urban areas, and some dry continental areas warming much more as they become further depleted of moisture and the capacity to offset potential warming by increased latent heat fluxes (Meehl et al., 2007). It is also not only temperature that will change. Many aspects of the global climate system would be expected to experience some degree of change associated with the warmer temperatures, including atmospheric and oceanic circulation, precipitation, atmospheric moisture, storminess and ecosystem responses.

Extremes of climate are also likely to change in future. The IPCC states that there will be an increased risk of more intense, more frequent and longer-lasting heat waves in a warmer future climate, and that events such as the European heat wave in 2003 would be more common (Meehl et al., 2007). Meehl and Tebaldi (2004) estimated that many of the areas that receive the most severe heat wave events in the present climate, such as western and southern United States and the Mediterranean, will experience the greatest increase in heat wave severity in the second half of the $21^{\text {st }}$ century. Meanwhile the presently less susceptible areas, such as France and northwest North America, will also experience increases in severity. This projected warming is partly related to base state circulation changes due to the increase in greenhouse gas concentrations. Clark et al. (2006) state that the largest increases in frequency, duration and magnitude of summer heat waves will be found over Europe, North and South America, and East Asia. Although there is a wide uncertainty range surrounding the projections for some regions, the increases are still expected to be substantially greater than the present climate even for the most conservative of simulations. Interestingly, Clark et al. (2006) also report that in some regions, changes in extremely hot days are significantly larger than changes in mean values. Similarly, Schär et al. (2004) have demonstrated substantial increases in extreme temperature variability for Europe in the latter half of the $21^{\text {st }}$ century, such that the statistical distribution of mean summer temperature shifts towards warmer conditions and becomes wider.

The European 2003 heat wave has been studied as an example of what a typical heat wave in a warmer climate might be like. For example, Beniston (2004) compared the 
statistical features of the 2003 heat wave in Basel, Switzerland, to past and future extreme temperatures from the HIRHAM4 regional climate model. The study concluded that the 2003 event could be used as an analog of summers in the coming decades because it mimicked many of the physical processes expected in a warmer climate; such as soil moisture depletion and the lack of convective rainfall from June to September, which are projected to occur with greater frequency in the future. Stott et al. (2004) illustrated that the HadCM3 Global Climate Model, driven by the SRES A2 scenario, projects the mean summer temperature to be greater than that of 2003 for more than half of the years by 2040, and that by 2100 , the 2003 summer would be classed as an anomalously cold summer relative to the new climate.

\subsection{Estimating the future risk of future temperature related mortality}

Previous estimates of future heat related mortality have included only limited treatment of uncertainty. A more complete treatment is desirable if the results are to be useful in quantitative risk assessment of the future. Here we discuss the major uncertainties in these estimates and suggest how they might be addressed. The main uncertainties that need consideration can be divided according to (1) temperature-mortality relationship modelling uncertainties, (2) climate projection uncertainties, and (3) vulnerable population modelling (see Figure 1).

Regarding temperature-mortality relationship modelling, the uncertainties include how hot days or heat waves are defined (previously discussed) and how excess deaths are calculated (previously discussed). The climate change uncertainty typically comprises contributions from: future emissions, representation of processes and definition of parameters within climate models, and downscaling of climate change to smaller scales. The vulnerable population modelling depends on future population estimates, and their distributions, and future adaptation, which might depend on future estimates of technology and wealth. Clearly, the potential vulnerable population for the future is unlikely to be independent of the emissions scenario, since they share many controlling factors. These uncertainties have a cascading effect such that each uncertainty builds to the next. As a result, the uncertainty inherent in the final impact is considerable (see Figure 1). Furthermore, while it is not a climate model uncertainty, natural variability in future climate projections can further broaden the range of health impacts projected for a given year in the future 


\subsubsection{Emissions uncertainty}

Future emissions of greenhouse gases from human activities depend upon socio-economic factors such as population, economic growth and technology. There are uncertainties in how these will change in the future, which means there is uncertainty surrounding the extent of warming projected for the future. To account for this uncertainty, the IPCC Special Report on Emission Scenarios (Nakićenović and Swart, 2000) produced four families of plausible and equally valid "storylines", or scenarios, detailing how these factors may develop in the future (Figure 2). Each family is labelled A1, A2, B2 and B1, which assume different increases in greenhouse gas emissions in the future. This set of scenarios consists of six scenario groups drawn from the four families, one group each in A2, B1, B2 (labelled A2, B1 and B2 respectively), and three groups within the A1 family (A1FI (fossil fuel intensive), A1B (balanced), and A1T (predominantly non-fossil fuel)). For the $21^{\text {st }}$ century, the HadCM3 climate model projects around a $2^{\circ} \mathrm{C}$ global average warming for the lowest scenario, B1, and $5^{\circ} \mathrm{C}$ for the highest, A1FI (see Figure 3(A)). None of the full set of 40 scenarios include explicit mitigation policy but some scenarios do have a climate forcing similar to the $21^{\text {st }}$ century component of mitigation scenarios (e.g. the SRES A1B and B1 scenarios are comparable with the WRE750 and 550 (Wigley et al., 1996) scenarios). One issue of particular interest to predicting future heat-related mortality over coming decades is that the warming up to 2040 is similar for each scenario. This indicates that the uncertainty in emissions scenario choice makes little contribution to uncertainty in climate change over the next 40 years but by 2100 it is much higher (Jenkins and Lowe, 2003; Stott and Kettleborough, 2002). The similarity in pre 2040 response is partly due to the large inertia of the climate system and partly due to the fact that while the $\mathrm{CO}^{2}$ emissions vary considerably between the SRES scenarios the total forcing (carbon dioxide, other greenhouse gases and aerosols) does not have such a large percentage spread early in the century. Emissions uncertainty is the most commonly examined source of uncertainty in predictions of future heat-related mortality (Koppe, 2005; Hayhoe et al., 2004; McMichael et al., 2003; Donaldson et al., 2001; Guest et al., 1999).

\subsubsection{Processes and parameters within climate models uncertainty}

Climate models attempt to represent the major processes within the climate system and are available in a range of complexities (Petoukhov et al., 2005; Gordon et al., 2000; Harvey et al., 1997). In this section we discuss models employed on large-scales, typically the planetary scale. The most complex models (global climate models; GCMs) typically represent the atmosphere, ocean, land surface, cryosphere, and biogeochemical processes, and solve the equations governing their evolution on a grid covering the globe. Some 
processes are represented explicitly within GCMs, for instance large-scale circulations, while others are represented by simplified parameterisations. The use of these parameterisations is sometimes due to processes taking place on scales smaller than the typical grid size of a GCM or sometimes to the current limited understanding of these processes. Furthermore, different modelling centres will use different plausible representations of the climate system, which is why climate projections for a single emissions scenario will differ between modelling centres (see Figure 3(B)).

Several strategies exist for estimating climate model uncertainty using ensembles of plausible models. One approach, involves collecting GCM results from several different models (e.g. Covey et al., 2003) to produce an ensemble of projections for comparison, such as in Figure 3(B). A limitation of this method is that it is not designed to span the complete range of model uncertainty. For example, all the models in the ensemble may have missed out some important processes which amplify or attenuate the change in climate, thus the uncertainty estimate must itself be considered uncertain. A second approach to estimating model uncertainty is by generating a "perturbed parameter" approach (Murphy et al., 2004) that introduces perturbations to the physical parameterisation schemes of a single model, leading to many plausible versions of the same underlying model. If sufficient computer power is available, then very large ensembles can be generated in this way. For example, Stainforth et al. (2005) ran an ensemble of 2,578 simulations that sampled combinations of low, intermediate, and high values of 6 parameters. One major advantage of this approach is that it addresses the criticism that climate models can be "tuned" to give the correct answer by modifying the model away from its tuned state (Stocker, 2004). No climate change-temperature related mortality studies have incorporated results from perturbed parameter ensembles.

\subsubsection{Downscaling uncertainty}

The spatial resolution of GCM results (typically $250 \mathrm{~km}$ ) is too coarse to be used directly in some impact studies. Thus, global GCM results must be downscaled to the finer scales needed (typically less than 50km). Two approaches are typically available, statistical downscaling and dynamic downscaling. The former uses statistical relationships to convert the large-scale projections from a GCM to fine scales, while the latter uses a dynamic model similar to a GCM to cover a region. The dynamic model is then forced at its lateral boundaries using results from the coarse scale GCM. The dynamic method is typically more computationally expensive but does not rely on the central assumption of most statistical downscaling, that the downscaling relationship derived for the present day will also hold in the future. Hayhoe et al. (2004) and McMichael et al. (2003) used statistical 
downscaling to examine the impacts of climate change on heat-related mortality in Los Angeles and 10 Australian cities respectively. Dessai (2003) applied dynamical downscaling, whilst the studies of Donaldson et al. (2001) and Guest et al. (1999) only used GCM data.

The ability to simulate extremes of temperature is different in global and regional climate models (RCMs). Figure 3(C) shows a regional climate model simulation having more hot days per year on average than the global model from which its boundary conditions were derived, except for the hottest day of the year. For instance, the regional model simulation has greater than $35 \%$ more days reaching $27^{\circ} \mathrm{C}$ than the global model. The temperature differences may be due to differences in the spatial resolution at which convective activity and cloud cover are modelled as well as differences in the representation of land cover. No studies have examined what the effects of different downscaling methods would be on mortality projections, or what differences there would be between applying downscaling and not applying it. Crop yield (Tsvetsinkskaya et al., 2003; Mearns et al., 2001) and tree range studies (Kueppers et al., 2005) have demonstrated significant differences in impacts dependent upon whether GCM or RCM data is used. For example, Kueppers et al. (2005) demonstrated the range of one species of California endemic oak shrunk by $59 \%$ if using RCM projections. Under a similar GCM-based scenario, the species retained $81 \%$ of its current range. This source of uncertainty deserves attention regarding climate change impacts on temperature related mortality.

\subsubsection{Use of observational constraints in future projections}

An uncertainty distribution estimated from model results alone is useful in establishing how sensitive the end results, e.g. excess mortality estimates, are to the modelling of climate. However, if all models are considered equally likely then the result may not provide a good estimator of risk. Some recent studies (Collins et al., 2006; Murphy et al., 2004) have used observational constraints to weight ensembles of future projections, thus treating some model versions as being more likely than others. One way of doing this is to score each model's ability to simulate the past or present day climate then use this to generate a likelihood for each model version's future projection. In a Bayesian framework (Moss and Schneider, 2000) the unweighted model results can be considered the prior distribution which are multiplied by the likelihood to obtain a posterior probability. This probability distribution can then be used as a risk estimator that incorporates both model results and observational evidence.

An alternative way to use models and observational constraints follows from the Detection and Attribution methodology (see section 3.1). This method involves comparing 
simulated and observed patterns of change to generate an uncertainty distribution and an estimate of model bias. These can be used to modify raw model projections of the future (Jones et al., 2006). This method typically uses fewer climate model simulations and observations from fewer variables than the weighted ensemble approach, but often uses a longer period of observations. It might be possible in the future to combine the two methods.

\subsubsection{Population change uncertainty}

Studies demonstrate that the elderly are at most risk to heat-related mortality (Hajat et al., 2007; Conti et al., 2005; Empereur-Bissonnet, 2004; Donaldson et al., 2003; Huynen et al., 2001). Therefore it is important to consider the demographic structure and population size in the future when examining the impacts of climate change on heat-related mortality. There are great uncertainties in projecting these outcomes but O'Neill (2004) argues these are smaller than the uncertainties associated with projections of the response of the climate system to greenhouse gas emissions and rates of technological progress. Nevertheless, this source of uncertainty is poorly represented. For example, Donaldson et al. (2001) and Hayhoe et al. (2004) assumed there would be no changes in population size or structure in the future despite considering emissions uncertainty, modelling uncertainty and downscaling uncertainty between them. McMichael et al. (2003) goes a step further and considers two population scenarios; one with an increase in population size and ageing, and another with no population change at all. Dessai (2003) estimated Lisbon's population up to 2100 by applying each SRES population growth storyline to the 1990 population. However, the median population from these calculations was used for simplicity. National downscaled population projections for each SRES storyline are available on the web site of the Centre for International Earth Science Information Network (CIESIN), so the potential exists to consider these in line with the SRES emissions scenarios. However, Kovats et al. (2003) state the CIESIN downscaling uses a relatively simple method that does not take into account different rates of growth of countries within the SRES regions and that the SRES scenarios are not intended to be used for assessment at the national level. Nevertheless, they still present a source of data with which to consider the uncertainty associated with population change.

\subsubsection{Adaptation uncertainty}

Adaptation includes physiological acclimatisation as well as a range of behavioural adaptations (e.g. dressing appropriately during hot weather) and technological adaptations (e.g. air conditioning or the introduction of heat health watch warning systems). Most 
temperature-mortality studies focus on modelling present relationships by time-series analysis (Páldy et al., 2005; Hajat et al., 2005; Davis et al., 2003a; O’Neill et al., 2003; Pattenden et al., 2003; Curriero et al., 2002; Hajat et al., 2002; Gemmell et al., 2000; Danet et al., 1999; Ballester et al., 1997), meaning that predictions of future mortality based on them assume the relationship is stationary; i.e. that future temperature-mortality relationships will be identical to past ones. However, it has been shown that such time series are non-stationary in nature (Davis et al., 2003a,b, 2002) so that they cannot be easily applied to future scenarios of climate- and demographic change. The effects of any potential adaptation to a changing climate imply that non-stationary models are required.

There is much debate as to how adaptation should be modelled. The majority of climate change-temperature related mortality studies usually only refer to physiological acclimatisation, but the three main available methods can be considered to include adaptation generally. Firstly, an approximation of the inherent adaptation trend can be removed from historical time series data by regression techniques prior to modelling the relationships - a method pioneered by Davis et al. (2004) to assess the impact of seasonal climate variability on mortality. Climate change scenarios can then be applied to the model. A limitation of removing the trend is that it does not attempt to model future adaptation per se, rather it provides an objective prediction that has controlled for historical adaptation.

The second method involves interpolatation of present dose-response relationships to the future (Dessai, 2003; Donaldson et al., 2001; Honda et al., 1998) so that the threshold temperature increases with time and/or the relationship is extrapolated at the warm and/or cold ends to handle more extreme temperatures possible with climate change. Obviously this method requires some assumption as to how much the dose-response relationship can be 'shifted'. For example, Dessai (2003) assumed adaptation to a $1^{\circ} \mathrm{C}$ warming would occur every three decades. This method perhaps gives a better representation of adaptation than the previous method. Furthermore, Honda et al. (1998) have presented empirical evidence illustrating that the threshold temperature has shifted between $23^{\circ} \mathrm{C}-28^{\circ} \mathrm{C}$ to over $33^{\circ} \mathrm{C}$ during the period 1972-1990 in Okinawa, Japan.

The third method involves the use of 'analog' or 'surrogate' cities (National Assessment Synthesis Team, 2000; Kalkstein and Greene, 1997) whose present climate best approximates the estimated climate of a target city as expressed by climate model projections. For example, assuming in the future that Charlotte's (North Carolina, US) population will have the same dose-response relationship as Atlanta's (Georgia, US). This method receives the most criticism because it inherently assumes stationarity of temperature-mortality relationships by using past ones to represent future ones. 
Furthermore it does not account for unique place-based socio-demographic characteristics of cities that are related to mortality (Smoyer, 1993); and there is evidence in the US that the dose-response relationships for different cities are becoming identical (Davis et al., 2004), thus rendering the method unusable. Hayhoe et al. (2004) employed "analog years" whereby future acclimatisation was based on the dose-response temperature-mortality relationship only in the hottest summers in the past record, as a way of approximating response in a warmer world.

\subsection{Findings}

\subsubsection{Decreased cold-related mortality offsetting increased heat-related mortality}

Although our focus is on high temperature events it is important that we note that changes in cold-related mortality may also occur. However, separating the hot and cold mortality projections, rather than presenting a net change, remains vital because adaptation is likely to be different for the two different types of event. Several national climate change health impact assessment reports point to increases in heat stress and heat-related mortality, especially amongst the elderly, in countries including Canada (Riedel, 2004), the Netherlands (Bresser, 2006), Spain (Moreno, 2005), Germany (Zebisch et al., 2005), the UK (Donaldson et al., 2001), the US (Ebi et al., 2006), Japan (Koike, 2006), Switzerland (Thommen Dombois and Braun-Fahrlaender, 2004), Portugal (Casimiro et al., 2006), and Australia (McMichael et al., 2003). However, the Finnish national assessment (Hassi and Mika Rytkönen, 2005) concludes that there will be little increase in heat related mortality to a $2^{\circ} \mathrm{C}$ warming, largely because heat-related mortality constitutes only $0.2-0.4 \%$ of all annual deaths in Finland. Further studies examining the impacts of climate change on health in the higher latitudes for a range of locations would be beneficial.

It has been suggested that increases in heat-related mortality may be offset by reductions in cold-related mortality, but there is discrepancy among the magnitudes of these changes. Some predictions give conservative estimates. For example, Davis et al. (2004) illustrated that a $1.5^{\circ} \mathrm{C}$ warming for any one of 28 US metropolitan areas would result in 3.61 additional deaths (per standard million) per year in summer, and 8.92 fewer deaths in winter, with a net annual decline of 2.65. Guest et al. (1999) also demonstrated a net decline of $8-12 \%$ in total mortality by 2030 for 5 Australian cities, depending upon whether the CSIROMk2 GCM was driven by a low or high warming scenario. In contrast, McMichael et al. (2003) concluded the increase in heat-related deaths across 10 Australian cities by 2050 was predicted to be far greater than the decrease in cold-related deaths. Their explanation for the difference was that Guest et al. (1999) did not adjust for the effect of pollution. Air pollution is higher in urban areas, especially during the winter because of 
increased home heating. Therefore a failure to consider it means the cold will appear to have a greater effect on mortality. Donaldson et al. (2001) have predicted severe impacts for the UK under the UKCIP98 Medium-High climate change scenario: a 253\% increase in annual heat-related mortality by the 2050 s with a minor reduction of $25 \%$ in cold-related mortality. Further supporting this are the findings of Langford and Bentham (1995), who estimated that a $2-2.5^{\circ} \mathrm{C}$ increase in winter temperature by 2050 would only result in a 2 $3 \%$ reduction in winter-time deaths in the UK. Kalkstein and Greene (1997) estimated a $70 \%$ increase in summer mortality and $15 \%$ decrease in winter mortality by the 2050 s for 44 US cities. Also, Koppe (2005) has estimated a $20 \%$ increase in heat-related mortality by the 2050s for Baden-Wuertemberg in Germany, when driving the ECHAM4 model with the SRES A1B scenario. Koppe (2005) concludes that the increase is unlikely to be offset be reductions in cold-related mortality. These differences highlight the requirement for further studies examining the extent to which the balance between increased heat-related deaths and reduced cold-related deaths will be affected by climate change.

\subsubsection{Consideration of uncertainties.}

Donaldson et al. (2001) examined the role of emissions uncertainty on predictions of UK heat-related mortality by considering the four UKCIP98 scenarios (Low, Medium-Low, Medium-High and High, corresponding to SRES B1, B2, A2 and A1FI marker scenarios) used as input for the HadCM2 GCM. The Medium-High scenario was most commonly used throughout the assessment. By the 2050s, this scenario estimated a $253 \%$ increase in heat-related deaths relative to present day. However, considering the Low and High scenarios the increase in mortality ranges between $71 \%$ and $307 \%$. The assessment assumed the dose-response relationship was stationary but extrapolated this at the warm end. Failing to account for possible acclimatisation means the results could be overestimates - Kalkstein (2005) has shown summer mortality in London (UK) would be almost a third lower by the late $21^{\text {st }}$ century with acclimatisation considered. Another assumption was that the GCM output has meaning at the scale of individual gridboxes because there was no downscaling.

Similarly, McMichael et al. (2003) included low, medium and high scenarios of climate change based on the SRES B1, A1B and A1FI emissions scenarios respectively, to examine heat-related mortality in 10 Australian cities. However, they also accounted for modelling uncertainty by driving two different models with the above scenarios; the CSIROMk2 and ECHAM4 models. Brisbane was observed to experience the worst effects by 2050 . Assuming no change in the demographic structure, a $164 \%$ increase in mortality was predicted under the CSIROMk2 High scenario. The ECHAM4 High scenario 
estimated a $157 \%$ increase. Considering the Low scenarios for each of these models, the increases in mortality were $51 \%$ and $50 \%$ respectively. Hence the predictions were more sensitive to emission scenario than choice of model. However, inclusion of other GCMs that captured more of the range in modelling uncertainty may have produced different results. The possible benefits of adaptation were not examined. Guest et al. (1999) included scenarios of Low and High climate change to drive the CSIROMk2 model to examine impacts in Australia's 5 largest cities. An interesting approach was to model the temperature-mortality relationship by applying either a TSI or non-linear regression. Based on a TSI they predicted total mortality to decrease by $8-12 \%$ by 2030 , assuming Low and High climate change respectively. Non linear regression yielded increases of $0.6 \%$ and $10 \%$ for the Low and High scenarios respectively. That the two different methodologies produced negative and positive effects highlights the importance in accounting for the various methodologies available to examine future impacts.

Casimiro et al. (2006) present heat-related mortality predictions for Lisbon based upon the findings of Dessai (2003). Dessai (2003) considered the uncertainties associated with the allowance for acclimatisation and the method of calculating excess mortality. Temperature data was also obtained from two different RCMs; HadRM2 and PROMES, to account for modelling uncertainty. Summer heat related mortality was predicted to increase from between 5.4-6.0 (per 100,000) to between 7.3-29.5 by the 2050s. The lower limit of this assumes acclimatisation occurs, excess mortality is calculated from a 30-day running mean, and is driven by HadRM2. The upper limit assumes no acclimatisation, a 30-day running mean to calculate excess mortality, and is driven by PROMES. Bayesian analysis allowed the relative effects of these uncertainties upon the mortality predictions to be quantified. Accounting for potential acclimatisation reduced summer mortality by $40 \%$ for the 2050s, compared with not considering it. However, the analysis indicated that heatrelated mortality was mostly affected by the choice of RCM and least by the method of calculating excess deaths. This is in agreement with the findings of McMichael et al. (2003) discussed previously.

Similar conclusions can be drawn from a study by Hayhoe et al. (2004). The PCM and HadCM3 GCMs were each driven by the SRES B1 and A1FI emissions scenarios to predict heat-related mortality in Los Angeles for the period 2070-2099. Potential for acclimatisation was included but it was assumed the demographic structure and population would not change. The lowest estimate was 319 deaths per year, compared to 165 deaths per year over the period 1961-1990, which assumed acclimatisation would occur with the PCM model driven by B1. The top estimate indicated there would be 1,429 deaths per year, for HadCM3 driven by A1FI with no acclimatisation. Allowance for acclimatisation 
generally lowered estimates by about 20-25\%, although choice of emissions scenario explained the largest differences in mortality, followed by choice of GCM. However, given that the range of uncertainty due to the representation of processes and definition of parameters within climate models is comparable to emissions uncertainty (see Figure 3), the inclusion of only 2 climate models to investigate the uncertainty means it is likely the true uncertainty range due to the representation of processes and definition of parameters within climate models was unaccounted for.

The results of these studies indicate that the magnitude of the predictions of heatrelated mortality under climate change scenarios remain uncertain. However, this is not a basis upon which to question their value. Instead, the range of possible outcomes should be examined as explicitly as possible in order to give a reliable indication of what is possible in the future, given the current understanding of climate science. The impacts also vary spatially, highlighting that predictions need to be location specific. The use of 'surrogate cities' may not be ideal, especially as the effects of climate change will be heterogeneous. The majority of studies examine mortality with respect to mean, minimum or maximum temperature, but climate models indicate an increase in the mean and variance of temperatures with climate change (McGregor et al., 2005; Beniston, 2004; Meehl and Tebaldi 2004; Schär et al., 2004). Therefore less is known about temperature variability and mortality, although there is some evidence that increased variability will have an effect on winter and summer mortality (Braga et al., 2001, 2002). Additional studies examining the role of temperature variance would also be useful.

\section{CONCLUSIONS}

Research into elevated atmospheric temperature and mortality has expanded since the early 1990s so that time-series, case-crossover and TSI methods, each with their own respective merits, have been used to examine temperature-mortality relationships at various temporal and spatial scales. Epidemiological methods are most common and there is an opportunity to apply TSIs to locations outside the US. U-, V-, or J-shaped relationships are often observed, dependent upon location-specific climatological and demographic characteristics. The elderly and those with existing diseases such as ischaemic heart disease, respiratory disease, cardiovascular disease, and chronic obstructive pulmonary disease are most susceptible to extreme temperatures, which typically occur with lags of less than 3 days for heat, and over 3 days for cold. Mortality displacements are often evident in the days after a heat wave. A more systematic investigation of lag effects is required and there is much scope to examine the factors influencing mortality displacement and the relative contribution this makes to mortality during heat waves amongst different locations and 
populations. No formal definition of a heat wave exists, so how these events are defined in such studies will be important. Furthermore a more consistent methodology for calculating excess mortality would enhance comparisons between studies.

Other environmental and socio-economic variables have been associated with mortality, not least air pollution and air-conditioning usage. The interaction between air pollution and temperature requires further quantification, and an investigation of the effects of temperature under air-conditioning saturation, and of the benefits that may occur with increased air-conditioning usage in Europe are unexplored avenues. Extreme heat events early in the season are most damaging to health, as are events of extended duration, although few studies examine this. Populations in warmer/colder regions are more resilient to the effects of heat/cold, suggesting there is some potential for acclimatisation; something that predictions of temperature-related mortality under climate change scenarios must take in to account through the use of non-stationary models. There is evidence that climate change will affect temperature-related mortality heterogeneously, so inter-regional comparisons that account for changes in the mean and variance of temperature are a necessity. Populations are also becoming more urbanised, and analyses of the influence of the urban heat island effect and the compounding influence of pollution on mortality would therefore be beneficial.

We have discussed many of the uncertainties that are inherent at each stage of the process of making projections of future heat-related mortality. While there are clearly still many advances to be made by considering each stage of the projection process in isolation - such as trying to improve the temperature-mortality relationship, or the global climate model, or inclusion of urban effects - there is a definite need to examine the combination of uncertainties from each stage of the process. This will reveal where future attempts to reduce the uncertainty are most usefully targeted. We also recommend that observations are used not only in the development of the temperature-mortality relationships but also to constrain future climate predictions. As advances do occur they should not only be considered useful for informing local adaptation planning, they should also be used to refine the "damage" functions used in integrated assessment models (Tol and Fankhauser, 1998). These types of models are typically used in planning potential greenhouse gas emission mitigation strategies and need to contain the latest impacts information. Additionally, as the signal of climate change becomes greater then the lessons learned from different types of adaptation at different locations should be incorporated into the models in order to improve them further.

Finally, the issue of uncertainty needs to be carefully conveyed to policy makers, highlighting where we believe there is robust predictive skill, and also where there is not. 


\section{ACKNOWLEDGEMENTS}

This study was supported with funding from the UK Natural Environment Research Council (NERC) and a Cooperative Awards in Sciences of the Environment (CASE) award from the UK Met Office. Thank you to Peter Good (Met Office Hadley Centre) for providing Figure 3(B). Thank you also to David Hassell (Met Office Hadley Centre) for the provision of RCM data used in Figure 3(C). Scott Sheridan (Kent State University), Debbie Hemming (Met Office Hadley Centre) and an anonymous reviewer are thanked for their comments on an earlier version of the manuscript.

\section{REFERENCES}

Anderson RN, Rosenberg HM (1998) Age standardization of death rates: implementation of the year 2000 standard. National Vital Statistics Reports, 47, National Center for Health Statistics, Hyattsville, MD

Armstrong B (2003) Fixed factors that modify the effects of time-varying factors: applying the case-only approach. Epidemiology 14: 467-472

Ballester F, Corella D, Perez-Hoyos S, Saez M, Hervas A (1997) Mortality as a function of temperature. A study in Valencia, Spain, 1991-1993. International Journal of Epidemiology 26: $551-561$

Basu R (2001) Characterizing the relationship between temperature and cardio-respiratory mortality among the elderly US population. PhD dissertation, Baltimore, MD: Bloomberg School of Public Health, Johns Hopkins University

Barnett AG (2007) Temperature and cardiovascular deaths in the US elderly. Epidemiology 18: $369-372$

Basu R, Samet JM (2002) Relation between elevated ambient temperature and mortality: a review of the epidemiological evidence. Epidemiologic Reviews 24: 190-202

Beniston M (2004) The 2003 heat wave in Europe: A shape of things to come? An analysis based on Swiss climatological data and model simulations. Geophysical Research Letters 31: doi 10.1029/2003GL018857.

Bower D, McGregor GR, Hannah DM, Sheridan SC (2007) Development of a Spatial Synoptic Classification Scheme for Western Europe. International Journal of Climatology, doi 10.1002/joc. 1501

Braga AL, Zanobetti A, Schwartz J (2001) The time course of weather-related deaths. Epidemiology 12: 662-667

Braga AL, Zanobetti A, Schwartz J (2002) The effect of weather on respiratory and cardiovascular deaths in 12 US cities. Environmental Health Perspectives 110: 859-863 
Bresser A (2006) The Effect of Climate Change in the Netherlands, Netherlands Environmental Assessment Agency, MNP Bilthoven, p 112

Calado RMD, Botelho JDS, Catarino J, Carreira M (2005) Portugal, Summer 2003 mortality: the heat waves influence. In: Kirch W, Menne B, Bertollini R (eds) Extreme Weather Events and Public Health Responses, Springer, New York, pp 89-97

Casimiro E, Calheiros C, Santos FD, Kovats S (2006) National Assessment of Human Health Effects of Climate Change in Portugal: Approach and Key Findings. Environmental Health Perspectives 114: 1950-1956

Chesnut LG, Breffle WS, Smith JB, Kalkstein LS (1998) Analysis of differences in hotweather-related mortality across 44 US metropolitan areas. Environmental Science and Policy 1: 59-70

Chen G, Zhang Y, Song G, Jiang L, Zhao N, Chen B, Kan H (2007) Is diurnal temperature range a risk factor for acute stroke death? International Journal of Cardiology 116: 408-409

Clark R, Brown S, Murphy J (2006) Modelling northern hemisphere summer heat extreme changes and their uncertainties using a physics ensemble of climate sensitivity experiments. Journal of Climate 19: 4418-4435

Collins M, Booth BBB, Harris GR, Murphy JM, Sexton DMH, Webb MJ (2006) Towards quantifying uncertainty in transient climate change. Climate Dynamics 27: 127-147

Conti S, Meli P, Minelli G, Solimini R, Toccaceli V, Vichi M, Beltrano C, Perini L (2005) Epidemiologic study of mortality during the Summer 2003 heat wave in Italy. Environmental Research 98: 390-399

Covey C, AchutaRao KM, Cubasch U, Jones P, Lambert SJ, Mann ME, Phillips TJ, Taylor KE (2003) An overview of results from the Coupled Model Intercomparison Project. Global and Planetary Change 37: 103-133

Curriero FC, Heiner KS, Samet JM, Zeger SL, Strug L, Patz JA (2002) Temperature and mortality in 11 cities of the eastern United States. American Journal of Epidemiology 155: 80-87

Danet S, Richard F, Montaye M, Beauchant F, Lemaire B, Graux C, Cottel D, Marecaux N, Amouyel P (1999) Unhealthy effects of atmospheric temperature and pressure on the occurrence of myocardial infarction and coronary deaths. Circulation 100: 1-7

Davis RE, Knappenberger PC, Novicoff WM, Michaels PJ (2002) Decadal changes in heatrelated human mortality in the Eastern US. Climate Research 22: 175-184

Davis RE, Knappenberger PC, Michaels PJ, Novicoff WM (2003a) Changing heat-related morality in the United States. Environmental Health Perspectives 111: 1712-1718

Davis RE, Knappenberger PC, Novicoff WM, Michaels PJ (2003b) Decadal changes in summer mortality in US cities. International Journal of Biometeorology 47: 166-175

Davis RE, Knappenberger PC, Michaels PJ, Novicoff WM (2004) Seasonality of climatehuman mortality relationships in US cities and impacts of climate change. Climate Research 26: 61-76 
de’ Donato F, Michelozzi P, De Sario M, D'Ippoliti D, D’Ovidio M, Kirchmayer U, Marino C, Palange S, Perucci CA (2006) The Italian Project for the Prevention of Heat Health Effects: Findings From Summer 2006. Epidemiology 17: S164-S165

Department of Health (2007) Heatwave Plan for England: 2007. Department of Health, London. See also: http://www.metoffice.gov.uk/weather/uk/heathealth/index.html

Dessai S (2002) Heat stress and mortality in Lisbon Part I. Model construction and validation. International Journal of Biometeorology 47: 6-12

Dessai S (2003) Heat stress and mortality in Lisbon Part II. An assessment of the potential impacts of climate change. International Journal of Biometeorology 48: 37-44

Donaldson GC, Keatinge WR, Näyhä S (2003) Changes in summer temperature and heatrelated mortality since 1971 in North Carolina, South Finland, and Southeast England. Environmental Research 91: 1-7

Donaldson GC, Kovats RS, Keatinge WR, McMicheal AJ (2001) Heat- and cold related mortality and morbidity and climate change. In: Maynard RL (ed) Health Effects of Climate Change in the UK, Department of Health, London, pp 70-80

Ebi KL, Mills DM, Smith JB, Grambsch A (2006) Climate change and human health impacts in the United States: an update on the results of the US national assessment. Environmental Health Perspectives 114: 1318-1324

Ellis FP (1978) Mortality in the elderly in a heatwave in New York City, August 1975. Environmental Research 15: 504-512

EM-DAT (2007), The OFDA/CRED International Disaster Database, Université Catholique de Louvain, Brussels, Belgium. http://www.emdat.be Cited 3 April 2008

Empereur-Bissonnet P (2004) Health impacts of the 2003 heat-wave in France. In: Kirch W, Menne B, Bertollini R (eds) Extreme Weather Events and Public Health Responses, Springer, New York, pp 21-22.

Eurowinter (1997) Cold exposure and winter mortality from ischaemic heart disease, cerebrovascular disease, respiratory disease, and all causes in warm and cold regions of Europe. The Lancet 349: 1341-1346

Filleul L, Cassadou S, Medina S, Fabres P, Lefranc A, Eilstein D, Le Tertre A, Pascal L, Chardon B, Blanchard M, Declercq C, Jusot J-F, Prouvost H, Ledrans M (2006) The Relation Between Temperature, Ozone, and Mortality in Nine French Cities During the Heat Wave of 2003. Environmental Health Perspectives 114: 1344-1347

French Institute for Public Health Surveillance (2006) Annual Report 2006. Institut de Veille Sanitaire, France

Gemmell I, McLoone P, Boddy FA, Dickinson GJ, Watt GCM (2000) Seasonal variation in mortality in Scotland. International Journal of Epidemiology 29: 274-279

Gordon C, Cooper C, Senior CA, Banks H, Gregory JM, Johns TC, Mitchell JFB, Wood RA (2000) The simulation of SST, sea ice extents and ocean heat transports in a version of the Hadley Centre coupled model without flux adjustments. Climate Dynamics 16: 147168 
Gosling SN, McGregor GR, Páldy A (2007) Climate change and heat-related mortality in six cities Part 1: model construction and validation. International Journal of Biometeorology 51: 525-540

Greene JS, Kalkstein LS (1996) Quantitative analysis of summer air masses in the eastern United States and an application to human mortality. Climate Research 7: 43-53

Guest CS, Willson K, Woodward AJ, Hennessy K, Kalkstein LS, Skinner C, McMichael AJ (1999) Climate and mortality in Australia: retrospective study, 1979-1990, and predicted impacts in five major cities in 2030. Climate Research 13: 1-15

Hajat S, Armstrong BJ, Baccini M, Biggeri A, Bisanti L, Russo A, Paldy A, Menne B, Kosatsky T (2006) Impact of high temperatures on mortality. Epidemiology 17: 632-638

Hajat S, Armstrong BJ, Gouveia N, Wilkinson P (2005) Mortality displacement of heatrelated deaths. A comparison of Delhi, São Paulo, and London. Epidemiology 16: 613-620

Hajat S, Kovats RS, Atkinson RW, Haines A (2002) Impact of hot temperatures on death in London: a time series approach. Journal of Epidemiology and Community Health 56: 367372

Hajat S, Kovats RS, Lachowycz K (2007) Heat-related and cold-related deaths in England and Wales: who is at risk? Occupational and Environmental Medicine 64: 93-10

Harvey LDD, Gregory J, Hoffert M, Jain A, Lal M, Leemans R, Raper SCB, Wigley TML, de Wolde JR (1997) An introduction to simple climate models used in the IPCC Second Assessment Report. In: Houghton JT, Meira Filho LG, Griggs DJ, Maskell K (eds.) IPCC Technical Paper 2, IPCC, Geneva, Switzerland

Hassi J, Rytkonen M (2005) Climate warming and health adaptation in Finland. FINADAPT Working Paper 7. Finnish Environment Institute Mimeographs, 337, Helsinki, p 28

Hayhoe K, Cayan D, Field CB, Frumhoff PC, Maurer EP, Miller NL, Moser SC, Schneider SH, Cahill KN, Cleland EE, Dale L, Drapek R, Hanemann RM, Kalkstein LS, Lenihan J, Lunch CK, Neilson RP, Sheridan SC, Verville JH (2004) Emissions pathways, climate change, and impacts on California. Proceedings of the National Academy of Sciences of the United States of America 101: 12422-12427

Hegerl GC, Karl TR, Allen MR, Bindoff NL, Gillett NP, Karoly DJ, Zhang X, Zwiers FW (2006) Climate change detection and attribution: Beyond mean temperature signals. Journal of Climate 19: 5058-5077

Honda Y, Ono M, Sasaki A, Uchiyama I (1998) Shift of the short term temperature mortality relationship by a climate factor: some evidence necessary to take account of in estimating the health effect of global warming. Journal of Risk Research 1: 209-220

Huynen MMTE, Martens P, Schram D, Weijenberg MP, Kunst AE (2001) The impact of heat waves and cold spells on mortality rates in the Dutch population. Environmental Health Perspectives 109: 463-470

Ingram W (2006) Detection and attribution of climate change, and understanding solar influence on climate. Space Science Reviews 125: 199-211 
Intergovernmental Panel on Climate Change (IPCC), Tegart WJMcG, Sheldon GW, Griffiths DC (eds) (1990) Climate Change - The IPCC Impacts Assessment Report prepared for IPCC by Working Group II. Australian Government Publishing Service, Canberra, p 277

Intergovernmental Panel on Climate Change (IPCC), McCarthy JJ, Canziani OF, Leary NA, Dokken DJ, White KS (eds) (2001) Climate Change 2001: Impacts Adaptation and Vulnerability. Cambridge University Press, Cambridge, p 1032.

Intergovernmental Panel on Climate Change (IPCC) (2007a) Climate Change 2007: Impacts Adaptation and Vulnerability: Summary for Policymakers. http://www.ipcc.ch/

Intergovernmental Panel on climate Change (IPCC) (2007b) A Report of Working Group 1 of the Intergovernmental Panel on Climate Change: Summary for Policymakers. http://www.ipcc.ch/

Jenkins G, Lowe J (2003) Handling uncertainties in the UKCIP02 scenarios of climate change: Hadley Centre technical note 44, Met Office, Exeter

Johnson H, Kovats RS, McGregor GR, Stedman J,Gibbs M, Walton H (2005) The impact of the 2003 heat wave on daily mortality in England and Wales and the use of rapid weekly mortality estimates. Euro Surveillance 10: 168-171

Jones CD, Cox P, Huntingford C (2006) Climate-carbon cycle feedbacks under stabilization: uncertainty and observational constraints. Tellus B 58: 603-613

Jones GS, Jones A, Roberts DL, Stott PA, Williams KD (2005) Sensitivity of globalscale climate change attribution results to inclusion of fossil fuel black carbon aerosol. Geophysical Research Letters 32 doi 10.1029/2005GL023370

Jones TS, Liang AP, Kilbourne EM (1982) Morbidity and mortality associated with the July, 1980 heatwave in St. Louis and Kansas City, MO. Journal of the American Medical Association 247: 3327-3331

Kaiser R, Le Tertre A, Schwartz J, Gotway CA, Daley WR, Rubin CH (2007) The effect of the 1995 heat wave in Chicago on all-cause and cause-specific mortality. American Journal of Public Health, Suppl 1: S158-62.

Kalkstein LS (1990) Climate change and public health: what do we know and where are we going? Environmental Impact Assessment Review 10: 383-392

Kalkstein LS (1991) A new approach to evaluate the impact of climate on human mortality. Environmental Health Perspectives 96: 145-150

Kalkstein LS (1993) Health and climate change - direct impacts in cities. Lancet 342: 1397-1399

Kalkstein LS (2005) A heat/mortality analysis for London: some climate change implications. A Roundtable on Climate Change and Heat: Implications for Public Health in the London Region, October 5 2005, London, UK. 
Kalkstein LS, Davis RE (1989) Weather and human mortality: an evaluation of demographic and interregional responses in the United States. Annals of the Association of American Geographers 79: 44-64

Kalkstein LS, Greene JS (1997) An evaluation of climate/mortality relationships in large US cities and the possible impacts of a climate change. Environmental Health Perspectives 105: 84-93

Kalkstein LS, Jamason PF, Greene JS, Libby J, Robinson L (1996) The Philadelphia hot weather-health watch/warning system: development and application, summer 1995. Bulletin of the American Meteorological Society 77: 1519-1528

Kalkstein LS, Smoyer KE (1993) The impact of climate change on human health: some international implications. Experientia 49: 969-979

Kalkstein LS, Valimont KM (1986) An evaluation of summer discomfort in the United States using a relative climatological index. Bulletin of the American Meteorological Society 67: 842-848

Kan H, London SJ, Chen H, Song G, Chen G, Jiang L, Zhao N, Zhang Y, Chen B (2007) Diurnal temperature range and daily mortality in Shanghai, China,' Environmental Research. 103: 424-431

Kassomenos PA, Gryparis A, Katsouyanni K (2007) On the association between daily mortality and air mass types in Athens, Greece during winter and summer. International Journal of Biometeorology 51: 315-322

Keatinge WR, Donaldson GC (2001) Mortality related to cold and air pollution in London after allowance for effects of associated weather patterns. Journal of Environmental Research Sect. A. 86: 209-216

Keatinge WR, Donaldson GC, Cordioloi E, Martinelli M, Kunst AE, Mackenbach JP, Nayha S (2000) Heat related mortality in warm and cold regions of Europe: observational study. British Medical Journal 321: 670-673

Kilbourne EM (1997) Heat waves and hot environments. In: Noji EJ (ed) The Public Health Consequences of Disasters, Oxford University Press, Oxford, pp 245-269

Kilbourne EM, Choi K, Jones TS, Thacker SB, The Field Investigation Team (1982) Risk factors in heat stroke: a case-control study. Journal of the American Medical Association 247: $3332-3336$

Klinenberg E (2002) Heat Wave: A Social Autopsy of Disaster in Chicago. University of Chicago Press, Chicago

Knowlton K, Lynn B, Goldberg RA, Rosenzweig C, Hogrefe C, Rosenthal JK, Kinney PL (2007) Projecting heat-related mortality impacts under a changing climate in the New York City region. American Journal of Public Health 97: 2028-2034

Koike I (2006) State of the art findings of global warming. Contributions of the Japanese researchers and perspective in 2006. The second report of the global warming initiative, climate change study 53 group, Ministry of Environment, Japan, Tokyo, pp 165-173. 
Koppe C (2005) Gesundheitsrelevante Bewertung von thermischer Belastung unter Berücksichtigung der kurzfristigen Anpassung der Bevölkerung and die lokalen Witterungsverhältnisse (Evaluation of health impacts of thermal exposure under consideration of short-term adaptation of populations to local weather; (in german). Berichte des Deutschen Wetterdienstes. 226, Offenbach am Main, p 167

Koppe C, Jendritzky G (2005) Inclusion of short-term adaptation to thermal stresses in a heat load warning procedure. Meteorologische Zeitschrift 14: 271-278

Koppe C, Kovats RS, Jendritzky G, Menna B (2004) Heat-waves: impacts and responses. In: Health and Global Environmental Change Series, No. 2. WHO Regional Office for Europe, Copenhagen

Kovats RS, Ebi K, Menne B (2003) Health and Global Environmental Change. Vol. 1: Methods of Assessing Human Health Vulnerability and Public Health Adaptation to Climate Change, Copenhagen, World Health Organization, Health Canada, United Nations Environmental Programme, World Meteorological Organization

Krieger N, Williams DR, Moss NE (1997) Measuring social class in US public health research: concepts, methodologies, and guidelines. Annual Review of Public Health 18: $341-378$

Kueppers LM, Snyder MA, Sloan LC, Zavaleta ES, Fulfrost B (2005) Modeled regional climate change and California endemic oak ranges. Proceedings of the National Academy of Sciences of the United States of America 102: 16281-16285

Kunst AE, Looman CW, Mackenbach JP (1993) Outdoor air temperature and mortality in The Netherlands: a time-series analysis. American Journal of Epidemiology 137: 331-341

Kyselý J (2007) Implications of enhanced persistence of atmospheric circulation for the occurrence and severity of temperature extremes. International Journal of Climatology 27: 689-695

Kyselý J, Huth R (2004) Heat-related mortality in the Czech Republic examined through synoptic and 'traditional' approaches. Climate Research 25: 265-274

Laaidi M, Laaidi K, Besancenot J-P (2006) Temperature-related mortality in France, a comparison between regions with different climates from the perspective of global warming. International Journal of Biometeorology 51: 145-153

Langford IH, Bentham G (2005) The potential effects of climate change on winter mortality in England and Wales. International Journal of Biometeorology 38: 141-147

Le Tertre A, Lefranc A, Eilstein D, Declercq C, Medina S, Blanchard M, Chardon B, Fabre P, Filleul L, Jusot J-F, Pascal L, Prouvost H, Cassadou S, Ledrans M (2006) Impact of the 2003 heatwave on all-cause mortality in 9 French cities. Epidemiology 17: 75-79

Maclure M (1991) The case-crossover design: a method for studying transient effects on the risk of acute events. American Journal of Epidemiology 133: 144-153

Martens P (1998) Health and Climate Change. Earthscan, London, p 176 
McGeehin MA, Mirabelli M (2001) The potential impacts of climate variability and change on temperature-related morbidity and mortality in the United States. Environmental Health Perspectives 109: 185-189

McGregor GR (1999) Winter ischaemic heart disease deaths in Birmingham, United Kingdom: a synoptic climatological analysis. Climate Research 13: 17-31

McGregor GR, Pelling M, Wolf T, Gosling SN (2006) The Social Impacts of Heat Waves. Report to Environment Agency, Environment Agency, Bristol, UK

McGregor GR, Markou MT, Bartzokas A, Katsoulis BD (2002) An evaluation of the nature and timing of summer human thermal discomfort in Athens, Greece. Climate Research 20: 83-94

McKee C (1989) Deaths in winter: can Britain learn from Europe? European Journal of Epidemiology 5: 178-182

McMichael AJ, Githeko A, Akhtar R, Carcavallo R, Gubler D, Haines A, Kovats RS, Martens P, Patz J, Sasaki A (2001) Human Health. In: McCarthy JJ, Canziani OF, Leary NA, Dokken DJ, White KS (eds) Climate Change 2001: Impacts, Adaptation, and Vulnerability, Cambridge University Press, Cambridge, pp 451-485

McMichael AJ, Haines A, Sloof R, Kovats S (1996) Climate Change and Human Health. World Health Organisation, Geneva

McMichael AJ, Woodruff R, Whetton P, Hennessy K, Nicholls N, Hales S, Woodward A, Kjellstrom T (2003) Human Health and Climate Change in Oceania: Risk Assessment 2002. Department of Health and Ageing, Canberra, Commonwealth of Australia, p 128

Mearns LO, Easterling W, Hays C, Marx D (2001) Comparison of Agricultural Impacts of Climate Change Calculated from High and Low Resolution Climate Change Scenarios: Part I. The Uncertainty Due to Spatial Scale. Climatic Change 51: 131-172

Meehl GA, Stocker TF, Collins WD, Friedlingstein P, Gaye AT, Gregory JM, Kitoh A, Knutti R, Murphy JM, Noda A, Raper SCB, Watterson IG, Weaver AJ, Zhao Z-C (2007) Global Climate Projections. In: Solomon S, Qin D, Manning M, Chen Z, Marquis M, Averyt KB, Tignor M, Miller HL (eds) Climate Change 2007: The Physical Science Basis. Contribution of Working Group I to the Fourth Assessment Report of the Intergovernmental Panel on Climate Change, Cambridge University Press, Cambridge, United Kingdom and New York, NY, US.

Meehl GA, Tebaldi C (2004) More intense, more frequent, and longer lasting heatwaves in the $21^{\text {st }}$ Century. Science 305: 994-997

Meehl GA, Washington WM, Collins WD, Arblaster JM, Hu A, Buja LE, Strand WG, Haiyan T (2005) How Much More Global Warming and Sea Level Rise? Science 307: 1769-1772

Michelon T, Magne P, Simon-Delavelle F (2005) Lessons of the 2003 heat-wave in France and action taken to limit the effects of future heat-waves. In: Kirch W, Menne B, Bertollini R (eds) Extreme Weather Events and Public Health Responses, Springer, New York, pp 131-140. 
Michelozzi P, de'Donato F, Bisanti L, Russo A, Cadum E, DeMaria M, D’Ovidio M, Costa G, Perucci CA (2005) Heat waves in Italy: cause specific mortality and the role of educational level and socio-economic conditions. In: Kirch W, Menne B, Bertollini R (eds) Extreme Weather Events and Public Health Responses, Springer, New York, pp 121-127.

Moreno J (2005) A preliminary assessment of the impacts in Spain due to the effects of climate change. ECCE project final report, Universidad de Castilla-La Mancha, Ministry of theEnvironment, Madrid, p 741

Moss R, Schneider S (2000) Uncertainties. In: Pachauri R, Taniguchi T, Tanaka K (eds) Guidance papers on the cross cutting issues of the third assessment report of the IPCC. IPCC, Geneva, pp 33-51

Murphy JM, Sexton DMH, Barnett DN, Jones GS, Webb MJ, Collins M, Stainforth DA (2004) Quantification of modelling uncertainties in a large ensemble of climate change simulations. Nature 430: 768-772

Nakićenović N, Swart R (2000) (eds) Special Report on Emission Scenarios. Cambridge University Press, Cambridge

National Assessment Synthesis Team (2000) Climate change impacts on the United States: the potential consequences of climate variability and change. US Global Change Research Program, Washington, DC

Naughton MP, Henderson A, Mirabelli MC, Kaiser R, Wilhelm JL, Kieszak SM, Rubin CH, McGeehin MA (2002) Heat-related mortality during a 1999 heat wave in Chicago. American Journal of Preventive Medicine 22:221-227

Oke TR (1987) Boundary Layer Climates. Routledge, London, p 435

O'Neill BC (2004) Conditional probabilistic population projections: An application to climate change. International Statistical Review 72: 167-184

O'Neill MS, Zanobetti A, Schwartz J (2003) Modifiers of the temperature and mortality associations in seven US cities. American Journal of Epidemiology 157: 1074-1082

ONS (Office for National Statistics) (2003) Summer mortality: deaths up in August heatwave. Available via ONS. http://www.statistics.gov.uk. Published online on $3^{\text {rd }}$ October 2003 at 9:30am

Páldy A, Bobvos J, Vámos A, Kovats RS, Hajat S (2005) The effect of temperature and heat waves on daily mortality in Budapest, Hungary, 1970-2000. In: Kirch W, Menne B, Bertollini R (eds) Extreme Weather Events and Public Health Responses, Springer, New York, pp 99-107

Pan WH, Li LA, Tsai MJ (1995) Temperature extremes and mortality from coronary heart disease and cerebral infraction in elderly Chinese. Lancet 345: 353-355

Pascal M, Laaidi K, Ledrans M, Baffert E, Caserio-Schönemann C, Le Tertre A, Manach J, Medina S, Rudant J, Empereur-Bissonnet P (2006) France's heat health watch warning system. International Journal of Biometeorology 50: 144-153

Pattenden S, Nikiforov B, Armstrong BJ (2003) Mortality and temperature in Sofia and London. Journal of Epidemiology and Community Health 57: 628-633 
Petoukhov V, Claussen M, Berger A, Cruci M, Eby M, Eliseev AV, Fichefet T, Ganopolski A, Goosse H, Kamenkovich I, Mokhov II, Montoya M, Mysak LA, Sokolov A, Stone P, Wang Z, Weaver AJ (2005) EMIC Intercomparison Project (EMIP-CO2): comparative analysis of EMIC simulations of climate, and of equilibrium and transient responses to atmospheric CO2 doubling. Climate Dynamics 25: 363-385

Redelmeier DA, Tibshirani RJ (1997) Interpretation and bias in case crossover studies. Journal of Clinical Epidemiology 50: 1281-1287

Riedel D (2004) Chapter 9: human health and well-being. In: Lemmen D, Warren F (eds) Climate Change. Impacts and adaptation. A Canadian perspective. Climate change impacts and adaptation directorate, Natural resources Canada, Ottawa, pp 151-171

Roberts S (2004) Interactions between particulate air pollution and temperature in air pollution mortality time series studies. Environmental Research 96: 328-337

Robinson PJ (2001) On the definition of a heat wave. Journal of Applied Meteorology 40: $762-775$

Rooney C, McMichael AJ, Kovats RS, Coleman MP (1998) Excess mortality in England and Wales, and in Greater London, during the 1995 heatwave. Journal of Epidemiology and Community Health 52: 482-486

Saez M, Sunyer J, Tobias A, Ballester F, Antó JM (2000) Ischaemic heart disease and weather temperature in Barcelona, Spain. European Journal of Public Health 10: 58-63.

Sakamoto-Momiyama M (1977) Seasonality in human mortality. University of Tokyo Press, Tokyo

Saldiva PHN, Pope CAIII, Schwartz J, Dockery DW, Lichtenfels AJ, Salge JM, Barone I, Böhm GM (1995) Air pollution and mortality in elderly people: a time series study in São Paulo, Brazil. Archives of Environmental Health 50: 159-163

Samet J, Zeger S, Kelsall J, Xu J, Kalkstein LS (1998) Does weather confound or modify the association of particulate air pollution with mortality? An analysis of the Philadelphia data 1973-1980. Environmental Research 77: 9-19

Sartor F, Snacken R, Demuth C, Walkiers D (1995) Temperature, ambient ozone levels and mortality during summer, 1994, in Belgium. Environmental Research 70: 105-113

Schär C, Vidale PL, Lüthi D, Frei C, Häberli C, Liniger MA, Appenzeller C (2004) The role of increasing temperature variability in European summer heatwaves. Nature 427: 332336

Schellnhuber HJ, Cramer W, Nakićenović N, Wigley T, Yohe G (2006) (eds) Avoiding Dangerous Climate Change. Cambridge University Press, Cambridge

Schwartz J (2000) The distributed lag between air pollution and daily deaths. Epidemiology 11: $320-326$

Schwartz J (2005) Who is sensitive to extremes of temperature? Epidemiology 16: 67-72 
Schwartz J, Dockery DW (1992) Increased mortality in Philadelphia associated with daily air pollution concentrations. American Review Of Respiratory Disease 145: 600-604

Semenza JC, Rubin CH, Falter KH, Selanikio JD, Flanders WD, Howe HL, Wilhelm JL (1996) Heat-related deaths during the July 1995 heat wave in Chicago. New England Journal of Medicine 335: 84-90

Sheridan SC (2002) The redevelopment of a weather-type classification scheme for North America. International Journal of Climatology 22: 51-68

Sheridan SC, Dolnev TJ (2003) Heat, mortality, and level of urbanization: measuring vulnerability across Ohio, US. Climate Research 24: 255-266

Sheridan SC, Kalkstein LS (2004) Progress in heat watch-warning system technology. Bulletin of the American Meteorological Society 85: 1931-1941

Smoyer KE (1993) Socio-demographic implications in summer weather-related mortality. MA thesis, University of Delaware, Newark

Smoyer KE (1998) Putting risk in its place: methodological considerations for investigating extreme event health risk. Social Science Medicine 47: 1809-1824

Smoyer KE, Rainham DG, Hewko JN (2000a) Heat-stress related mortality in five cities in Southern Ontario: 1980-1996. International Journal of Biometeorology 44: 190-197

Smoyer KE, Kalkstein LS, Greene JS (2000b) The impacts of weather and pollution on human mortality in Birmingham, Alabama and Philadelphia, Pennsylvania. International Journal of Climatology 20: 881-897

Stainforth A, Aina T, Christensen C, Collins M, Faull N, Frame DJ, Kettleborough JA, Knight S, Martin A, Murphy JM, Piani C, Sexton D, Smith LA, Spicer RA, Thorpe AJ, Allen MR (2005) Uncertainty in predictions of the climate response to rising levels of greenhouse gases. Nature 433: 403-406

Stocker TF (2004) Climate change: Models change their tune. Nature 430: 737-738

Stott PA, Kettleborough JA (2002) Origins and estimates of uncertainty in predictions of twenty-first century temperature rise. Nature 416: 723-726

Stott PA, Stone DA, Allen MR (2004) Human contribution to the European heatwave of 2003. Nature 432: 610-613

Tan J, Kalkstein LS, Huang J, Lin S, Yin H, Shao D (2004) An operational heat/health warning system in Shanghai. International Journal of Biometeorology 48: 157-162

Tan J, Zheng Y, Song G, Kalkstein LS, Kalkstein A, Tang X (2007) Heat wave impacts on mortality in Shanghai, 1998 and 2003. International Journal of Biometeorology 51: 193200

Thommen Dombois O, Braun-Fahrlaender C (2004) Health impacts of climate change with relevance for Switzerland. Insititut fuer Sozial- und Preventivmedizin der Universitaet Basel, Bundesamtfuer Gesundheit, Bundesamt fuer Umwelt, Wald und Landschaft, Basel, p 85 
Tol RSJ, Fankhauser S (1998) On the representation of impact in integrated assessment models of climate change. Environmental Modelling and Assessment 3: 63-74

Tsvetsinkskaya EA, Mearns LO, Mavromatis T, Gao W, McDaniel L, Downtown MW (2003) The Effect of Spatial Scale of Climatic Change Scenarios on Simulated Maize, Winter Wheat, and Rice Production in the Southeastern United States. Climatic Change 60: $37-71$

Vandentorren S, Suzan F, Medina S, Pascal M, Maulpoix A, Cohen J-C, Ledrans M (2004) Mortality in 13 French Cities During the August 2003 Heat Wave. American Journal of Public Health 94: 1518-1520

Vavrus SJ, Walsh JE, Chapman WL, Portis D (2006) The behaviour of extreme cold air outbreaks under greenhouse warming. International Journal of Climatology 26:1133-1147

Watts JD, Kalkstein LS (2004) The development of a warm weather relative stress index for environmental applications. Journal of Applied Meteorology 43: 503-513

Whitman S, Good G, Donoghue ER, Benbow N, Shou W, Mou S (1997) Mortality in Chicago attributed to the July 1995 heat wave. American Journal of Public Health 87: $1515-1518$

WHO (1980) Ninth International Classification of Diseases. WHO, Geneva

WHO (2003) Climate Change and Human Health - Risks and Responses - Summary. WHO, Geneva, p 37

WHO Regional Committee for Europe (2003) Briefing Note for the Fifty-Third Session of the WHO Regional Committee for Europe, Vienna, 8-11 September 2003, WHO, Geneva.

Wigley T, Richels R, Edmonds J (1996) Economic and environmental choices in the stabilization of atmospheric CO2 concentration. Nature 379: 242-245

Zebisch M, Grothmann T, Schroeter D, Hasse C, Fritsch U, Cramer W (2005) Climate change in Germany. Vulnerability and adaptation of climate sensitive sectors. Federal Environmental Agency (Umweltbundesamt), Dessau, p 205 
Table 1 List of Heat Events by region and country during the period 2000-2007. Numbers shown are fatalities. Data extracted from the Emergency Events Database, EM-DAT (2007). The database is compiled from sources including UN agencies, governmental and non-governmental agencies, insurance companies, research institutes and press agencies. A heat event is only entered in the database if at least two sources report the heat event's occurrence in terms of the number of people killed. 10 fatalities is the minimum for a reported event. In many cases event dates are at the monthly scale with the assumption that fatality statistics are associated with a distinct event within the noted month.

\begin{tabular}{|c|c|c|c|}
\hline Region & Country & Date & Killed \\
\hline \multirow{2}{*}{ North Africa } & Algeria & July 2003 & 40 \\
\hline & Morocco & August 2003 & \\
\hline West Africa & Nigeria & June 2002 & 60 \\
\hline \multirow{6}{*}{ North America } & US & July-August 2006 & 24 \\
\hline & US & July-August 2006 & 164 \\
\hline & US & July 2005 & 33 \\
\hline & US & June 2002 & 14 \\
\hline & US & August 2001 & 56 \\
\hline & US & July 2000 & 35 \\
\hline \multirow{15}{*}{ East Asia } & China & May-Sept 2006 & 134 \\
\hline & China & July 2004 & 39 \\
\hline & China & July 2002 & 7 \\
\hline & Japan & July 2004 & 10 \\
\hline & Bangladesh & May-June 2003 & 62 \\
\hline & India & May 2006 & 47 \\
\hline & India & June 2005 & 329 \\
\hline & India & May-June 2003 & 1,210 \\
\hline & India & May 2002 & 1,030 \\
\hline & India & April 2000 & 7 \\
\hline & Pakistan & May 2006 & 84 \\
\hline & Pakistan & June 2005 & 106 \\
\hline & Pakistan & May-June 2003 & 200 \\
\hline & Pakistan & May 2002 & 113 \\
\hline & Pakistan & June 2000 & 24 \\
\hline \multirow{2}{*}{ Western Asia } & Cyprus & July 2000 & 5 \\
\hline & Turkey & July 2000 & 15 \\
\hline \multirow{5}{*}{ Eastern Europe } & Bulgaria & June-July 2000 & 8 \\
\hline & Romania & June-July 2006 & 26 \\
\hline & Romania & July-August 2005 & 13 \\
\hline & Romania & July 2004 & 27 \\
\hline & Russia & July 2001 & 276 \\
\hline Northern Europe & UK & August 2003 & 2,045 \\
\hline \multirow{12}{*}{ Southern Europe } & Albania & July 2004 & 3 \\
\hline & Canary Islands & July 2004 & 13 \\
\hline & Croatia & July 2000 & 40 \\
\hline & Greece & July 2000 & 3 \\
\hline & Italy & July-August 2003 & 20,089 \\
\hline & Macedonia & July 2004 & 15 \\
\hline & Portugal & July 2006 & 41 \\
\hline & Portugal & August 2003 & 2,007 \\
\hline & Serbia-Montenegro & July 2000 & 3 \\
\hline & Spain & July 2006 & 21 \\
\hline & Spain & July 2004 & 26 \\
\hline & Spain & August 2003 & 141 \\
\hline \multirow{9}{*}{ Western Europe } & Belgium & July 2006 & 940 \\
\hline & Belgium & August 2003 & 150 \\
\hline & France & July 2006 & 1388 \\
\hline & France & August 2003 & 19,490 \\
\hline & Germany & July 2006 & 12 \\
\hline & Germany & August 2003 & 5,250 \\
\hline & Netherlands & July 2006 & 1,000 \\
\hline & Netherlands & August 2003 & 1,200 \\
\hline & Switzerland & July 2003 & 1,039 \\
\hline
\end{tabular}


Table 2 Advantages and disadvantages of the various methods for calculating excess mortality.

\begin{tabular}{|c|c|c|c|}
\hline Method & Reference & Advantages & Disadvantages \\
\hline $\begin{array}{l}\text { Compare mortality with a baseline calculated as the } \\
\text { temperature range at which mortality is at a } \\
\text { minimum. }\end{array}$ & Donaldson et al. $(2001,2003)$ & $\begin{array}{l}\text { Can allow comparison of excess mortality in } \\
\text { different geographical locations. }\end{array}$ & $\begin{array}{l}\text { Must account for fact that temperatures at } \\
\text { which minimum mortality occurs will vary } \\
\text { spatially and temporally. }\end{array}$ \\
\hline $\begin{array}{l}\text { Daily mortality compared with } 31 \text { - or } 30 \text {-day moving } \\
\text { average for the same year. }\end{array}$ & $\begin{array}{l}\text { Gosling et al. (2007) } \\
\text { Dessai (2002, 2003) } \\
\text { Rooney et al. (1998) }\end{array}$ & $\begin{array}{l}\text { Useful where long time series' of data are } \\
\text { unavailable. }\end{array}$ & $\begin{array}{l}\text { Inclusion of heat wave days in the mean } \\
\text { values can inhibit comparison between } \\
\text { different extreme events because of } \\
\text { differences in their duration. }\end{array}$ \\
\hline $\begin{array}{l}\text { Daily mortality compared with } 31 \text { - or } 30 \text {-day moving } \\
\text { average for } 2 \text { preceding years combined. }\end{array}$ & Huynen et al. (2001) & $\begin{array}{l}\text { Avoids the limitation associated with using a } \\
\text { moving average derived from the same year } \\
\text { and may therefore be considered more } \\
\text { reliable. }\end{array}$ & $\begin{array}{l}\text { Excesses at the start of data sets cannot be } \\
\text { calculated due to no data being available for } \\
\text { preceding years. }\end{array}$ \\
\hline $\begin{array}{l}\text { Daily mortality compared with fixed mean of daily } \\
\text { mortality for each month in previous years (i.e. for } \\
\text { the baseline, each month will have one value). }\end{array}$ & $\begin{array}{l}\text { Dessai }(2002,2003) \\
\text { Jones et al. }(1982)\end{array}$ & $\begin{array}{l}\text { Can be used if few years of previous data are } \\
\text { available. }\end{array}$ & $\begin{array}{l}\text { Excesses at the start of data sets can not be } \\
\text { calculated due to no data being available for } \\
\text { preceding years. }\end{array}$ \\
\hline $\begin{array}{l}\text { Baseline generated by Poisson regression and non- } \\
\text { parametric smoothing techniques. }\end{array}$ & $\begin{array}{l}\text { Le Tertre et al. (2006) } \\
\text { Gemmell et al. (2000) } \\
\text { Páldy et al. (2005) } \\
\text { Hajat et al. (2002) } \\
\text { Whitman et al. (1997) } \\
\text { Guest et al. (1999) }\end{array}$ & $\begin{array}{l}\text { Allows modelling of inherent seasonal } \\
\text { patterns in mortality (seasonality) and } \\
\text { adjustments for other important factors such } \\
\text { as influenza indicators, } \mathrm{PM}_{10} \text {, and relative } \\
\text { humidity. }\end{array}$ & $\begin{array}{l}\text { May not be applicable if there are limitations } \\
\text { on data availability. }\end{array}$ \\
\hline $\begin{array}{l}\text { Corresponding day of previous year, or mean from } \\
\text { several years. }\end{array}$ & $\begin{array}{l}\text { Conti et al. (2005) } \\
\text { Michelozzi et al. (2005) } \\
\text { ONS (2003) } \\
\text { Sartor et al. (1995) } \\
\end{array}$ & $\begin{array}{l}\text { Can be used if few years of previous data are } \\
\text { available (e.g. Conti et al. (2005) used } 1 \text { year - } \\
\text { 2002). }\end{array}$ & $\begin{array}{l}\text { Better to use a larger data set if using this } \\
\text { method (e.g. Sartor et al. (1995) used 1985- } \\
\text { 1993, and ONS (2003) used 1998-2002). }\end{array}$ \\
\hline $\begin{array}{l}\text { The median mortality for the month in which the } \\
\text { deaths occurred is subtracted from each day's } \\
\text { mortality count. }\end{array}$ & Davis et al. (2003) & $\begin{array}{l}\text { Ideal for a non-normal data set where the use } \\
\text { of a monthly mean would not be appropriate. }\end{array}$ & $\begin{array}{l}\text { Median may not be a true representation of } \\
\text { 'baseline' mortality. }\end{array}$ \\
\hline Subtract annual mean from monthly value & Davis et al. (2004) & Can be used with only 1 year of data. & Based on a limited time period. \\
\hline
\end{tabular}


Table 3 Studies incorporating only environmental variables, including summary of findings related to the variables examined.

\begin{tabular}{|c|c|c|c|}
\hline $\begin{array}{l}\text { Environmental } \\
\text { variables }\end{array}$ & Reference & Country & Summary of findings \\
\hline $\begin{array}{l}\text { Daily morning } \\
\text { temperature. }\end{array}$ & $\begin{array}{l}\text { Davis et al. } \\
\text { (2004) }\end{array}$ & US & $\begin{array}{l}\text { Relationship between monthly mortality and temperature decreased } \\
\text { between 1964-1998 ( } 28 \text { US cities). Concluded that climate change will } \\
\text { have little effect on mortality. }\end{array}$ \\
\hline Apparent Temperature & $\begin{array}{l}\text { Whitman et al. } \\
\text { (1997) }\end{array}$ & US & $\begin{array}{l}\text { No significant relationship between summer daily temperature and } \\
\text { mortality over } 16 \text { years (Chicago). }\end{array}$ \\
\hline $\begin{array}{l}\text { Daily minimum } \\
\text { temperature. }\end{array}$ & Schwartz (2005) & US & $\begin{array}{l}\text { Persons with diabetes are at higher risk to death on hot days, and persons } \\
\text { with chronic obstructive pulmonary disease (COPD) to death on cold } \\
\text { days (Wayne County, Michigan). }\end{array}$ \\
\hline $\begin{array}{l}\text { Daily temperature, dew } \\
\text { point temperature, and } \\
\mathrm{PM}_{10} \text {. }\end{array}$ & Roberts (2004) & US & $\begin{array}{l}\text { Effect of daily PM pollution may depend on temperature (Cook County, } \\
\text { Illinois and Allegheny County, Pennsylvania) }\end{array}$ \\
\hline 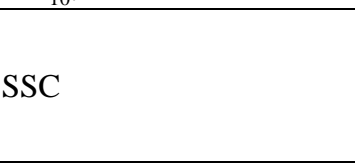 & $\begin{array}{l}\text { Kalkstein and } \\
\text { Greene (1997) }\end{array}$ & US & $\begin{array}{l}\text { High excess mortality associated with a very warm moist air mass and a } \\
\text { hot, dry air mass. Southern cities showed weaker relationships in summer. } \\
\text { By } 2020 \text { and } 2050 \text {, predicted summer mortality much higher than present, } \\
\text { even if people acclimatise. }\end{array}$ \\
\hline Daily CET, $\mathrm{NO}_{2}, \mathrm{PM}_{10}$ & $\begin{array}{l}\text { Rooney et al. } \\
(1998)\end{array}$ & UK & $\begin{array}{l}\text { Daily mortality in England \& Wales during } 1995 \text { heat wave rose } 8.9 \% \\
\text { above the seasonal average. Air pollution may have accounted for up to } \\
62 \% \text { of excess mortality. }\end{array}$ \\
\hline $\begin{array}{l}\text { Mean daily temperature, } \\
\text { relative humidity, } \mathrm{SO}_{2} \\
\mathrm{O}_{3} \text {, and black smoke. }\end{array}$ & $\begin{array}{l}\text { Hajat et al. } \\
(2002)\end{array}$ & UK & $\begin{array}{l}\text { Mortality higher if heat wave occurs earlier in summer (London, for } \\
\text { 1976-1996). Air pollution data had little influence on mortality. Min } \\
\text { temperature influenced mortality more than max temperature. }\end{array}$ \\
\hline 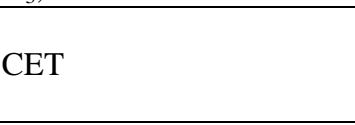 & $\begin{array}{l}\text { Donaldson et al. } \\
(2001)\end{array}$ & UK & $\begin{array}{l}\text { Assuming stationarity of present temperature-mortality relationships and } \\
\text { no acclimatisation, a } 253 \% \text { increase in heat-related mortality predicted for } \\
2050 \text { s but a decline in winter mortality (UK). }\end{array}$ \\
\hline $\begin{array}{l}\text { Mean daily temperature, } \\
\text { wind speed and relative } \\
\text { humidity. }\end{array}$ & $\begin{array}{l}\text { Donaldson et al. } \\
(2003)\end{array}$ & $\begin{array}{l}\text { UK } \\
\text { US } \\
\text { Finland }\end{array}$ & $\begin{array}{l}\text { Mortality more sensitive to cold in warmer regions (North Carolina) than } \\
\text { cooler ones (S.E. England) and vice versa. Other variables only used for } \\
\text { qualitative analysis. Annual heat-related mortality declined between } \\
\text { 1971-1997 for all locations. }\end{array}$ \\
\hline $\begin{array}{l}\text { Mean daily temperature, } \\
\text { relative humidity, and } \\
\text { particulate matter. }\end{array}$ & $\begin{array}{l}\text { Pattenden et al. } \\
(2003)\end{array}$ & $\begin{array}{l}\text { UK } \\
\text { Bulgaria }\end{array}$ & $\begin{array}{l}\text { Significant temperature-mortality associations (London and Sofia). Effect } \\
\text { of cold greater in city with warmer climate (London). Particulate matter } \\
\text { significantly effected mortality in Sofia but not London. }\end{array}$ \\
\hline $\begin{array}{l}\text { Daily mean, maximum, } \\
\text { minimum, and apparent } \\
\text { temperature, black } \\
\text { smoke and ozone. }\end{array}$ & $\begin{array}{l}\text { Hajat et al. } \\
(2006)\end{array}$ & $\begin{array}{l}\text { UK } \\
\text { Hungary } \\
\text { Italy }\end{array}$ & $\begin{array}{l}\text { Examined the "heat wave effect", i.e. the extra deaths occurring above } \\
\text { what would be expected from a smooth temperature-mortality gradient } \\
\text { relationship, due to consecutive days of high temperatures (heat waves). } \\
\text { An additional "heat wave" effect of 5.5\% was observed in London (1976- } \\
2003), 9.3 \% \text { in Budapest (1970-2000), and } 15.2 \% \text { in Milan (1985-2002). } \\
\text { Daily mean temperature gave the best fit to mortality. }\end{array}$ \\
\hline $\begin{array}{l}\text { Mean daily temperature, } \\
\text { pressure, relative } \\
\text { humidity, } \mathrm{PM}_{10} \text {. }\end{array}$ & $\begin{array}{l}\text { Páldy et al. } \\
(2005)\end{array}$ & Hungary & $\begin{array}{l}5^{\circ} \mathrm{C} \text { increase in temperature increased risk of total mortality by } 10.6 \% \text { in } \\
\text { Budapest. Relationship between } \mathrm{PM}_{10} \text { and mortality were weaker. } \\
\text { First heat wave in a year has highest mortality-impact. }\end{array}$ \\
\hline $\begin{array}{l}\text { Mean daily temperature, } \\
\text { relative humidity, and } \\
\text { suspended particulates. }\end{array}$ & $\begin{array}{l}\text { Ballester et al. } \\
\text { (1997) }\end{array}$ & Spain & $\begin{array}{l}\text { Significant temperature-mortality relationships in Valencia, annually, and } \\
\text { in winter and summer months respectively. Influence of humidity found } \\
\text { to be insignificant }\end{array}$ \\
\hline $\begin{array}{l}\text { Mean daily temperature, } \\
\text { relative humidity, black } \\
\text { smoke, } \mathrm{SO}_{2}, \mathrm{O}_{3}, \mathrm{NO}_{2} \text {. }\end{array}$ & $\begin{array}{l}\text { Saez et al. } \\
(2000)\end{array}$ & Spain & $\begin{array}{l}\text { Humidity influenced the temperature at which the onset of excess } \\
\text { ischaemic heart disease deaths occurred (Barcelona). }\end{array}$ \\
\hline $\begin{array}{l}\text { Humidex index (a } \\
\text { function of temperature } \\
\text { and vapour pressure). }\end{array}$ & $\begin{array}{l}\text { Conti et al. } \\
(2005)\end{array}$ & Italy & $\begin{array}{l}92 \% \text { of excess deaths in summer } 2003 \text { heat wave were amongst elderly. } \\
\text { Largest excesses were in the northwestern, cooler cities. }\end{array}$ \\
\hline TSI and black smoke & $\begin{array}{l}\text { Kassomenos et } \\
\text { al. (2007) }\end{array}$ & Greece & $\begin{array}{l}6 \text { air masses were observed for the warm months (April-October) for } \\
\text { Athens, 1987-1991. The most unfavourable to mortality was associated } \\
\text { with a sea breeze that promoted warm and humid conditions. These } \\
\text { associations were independent of black smoke concentrations. }\end{array}$ \\
\hline Mean daily temperature & $\begin{array}{l}\text { Huynen et al. } \\
(2001)\end{array}$ & Netherlands & $\begin{array}{l}\text { Largest excess mortality associated with longest lasting heat waves } \\
\text { (Netherlands). Some forward displacement of deaths during heat waves } \\
\text { but not during cold spells. }\end{array}$ \\
\hline $\begin{array}{l}\text { Mean daily temperature } \\
\text { and relative humidity. }\end{array}$ & $\begin{array}{l}\text { Dessai }(2002, \\
\text { 2003) }\end{array}$ & Portugal & $\begin{array}{l}\text { Significant temperature-mortality relationships observed in Lisbon for } \\
\text { period 1980-1998. Relative humidity was not significant. }\end{array}$ \\
\hline $\begin{array}{l}\text { Mean daily temperature, } \\
\text { relative humidity, } \\
\text { suspended particulates, } \\
\mathrm{SO}_{2}, \mathrm{O}_{3}, \mathrm{NO}_{2}, \mathrm{NO}_{\mathrm{x}}\end{array}$ & $\begin{array}{l}\text { Sartor et al. } \\
(1995)\end{array}$ & Belgium & $\begin{array}{l}\text { Most likely causes of elevated excess mortality during Summer } 1994 \text { in } \\
\text { Belgium were high outdoor temperatures combined with high ozone } \\
\text { concentrations. }\end{array}$ \\
\hline Minimum temperature on & Le Tertre et al. & France & Usual air pollution and temperature effects did not appear as the main \\
\hline
\end{tabular}




\begin{tabular}{|l|l|l|l|}
\hline $\begin{array}{l}\text { the current day, } \\
\text { maximum temperature } \\
\text { on the previous day, } \mathrm{O}_{3}\end{array}$ & $(2006)$ & & $\begin{array}{l}\text { factors affecting mortality in 9 cities during the 2003 France heat wave. } \\
3,096 \text { extra deaths were estimated to have resulted from the heat wave. } \\
\text { Little evidence of mortality displacement. }\end{array}$ \\
\hline $\begin{array}{l}\text { Diurnal temperature } \\
\text { range }(\mathrm{DTR}), \mathrm{PM}_{10}, \mathrm{SO}_{2},\end{array}$ & $\begin{array}{l}\text { Kan et al. } \\
(2007)\end{array}$ & $\begin{array}{l}\text { A C increment of the 3-day moving average of DTR corresponded to a } \\
\mathrm{O}_{3}, \mathrm{NO}_{2} .37 \% \text { increase in total mortality (Shanghai, 2001-2004). Uncertain } \\
\text { whether air pollution variables were confounders or effect moderators of } \\
\text { the DTR-mortality association. }\end{array}$ \\
\hline
\end{tabular}


Table 4 Studies incorporating environmental and socio-economic/lifestyle variables, including summary

of findings related to the variables examined.

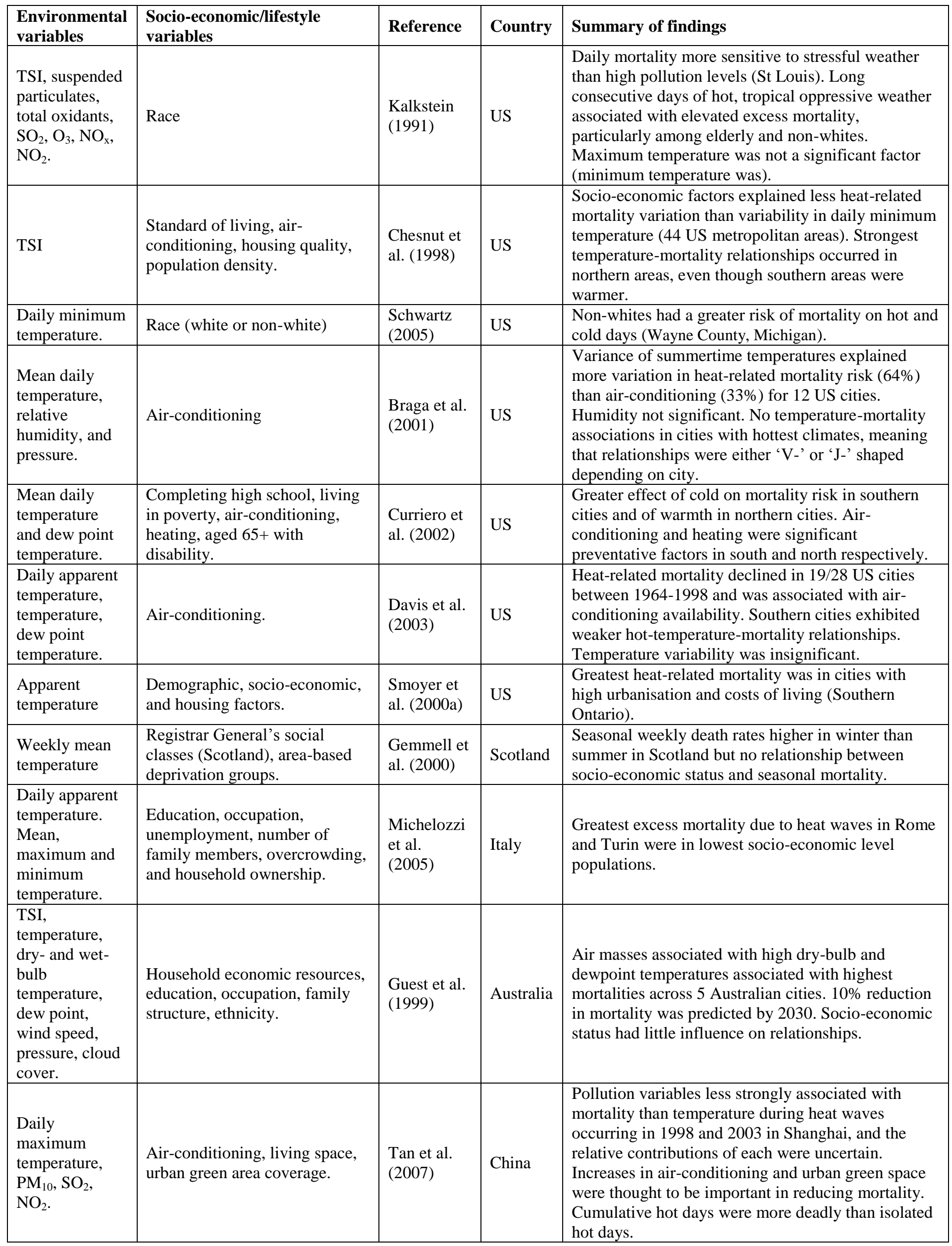


Table 5 Evidence for temperature bands of minimum mortality in order of increasing distance from the Equator, including age groups examined, causes of death, and nature of relationships (if stated in study).

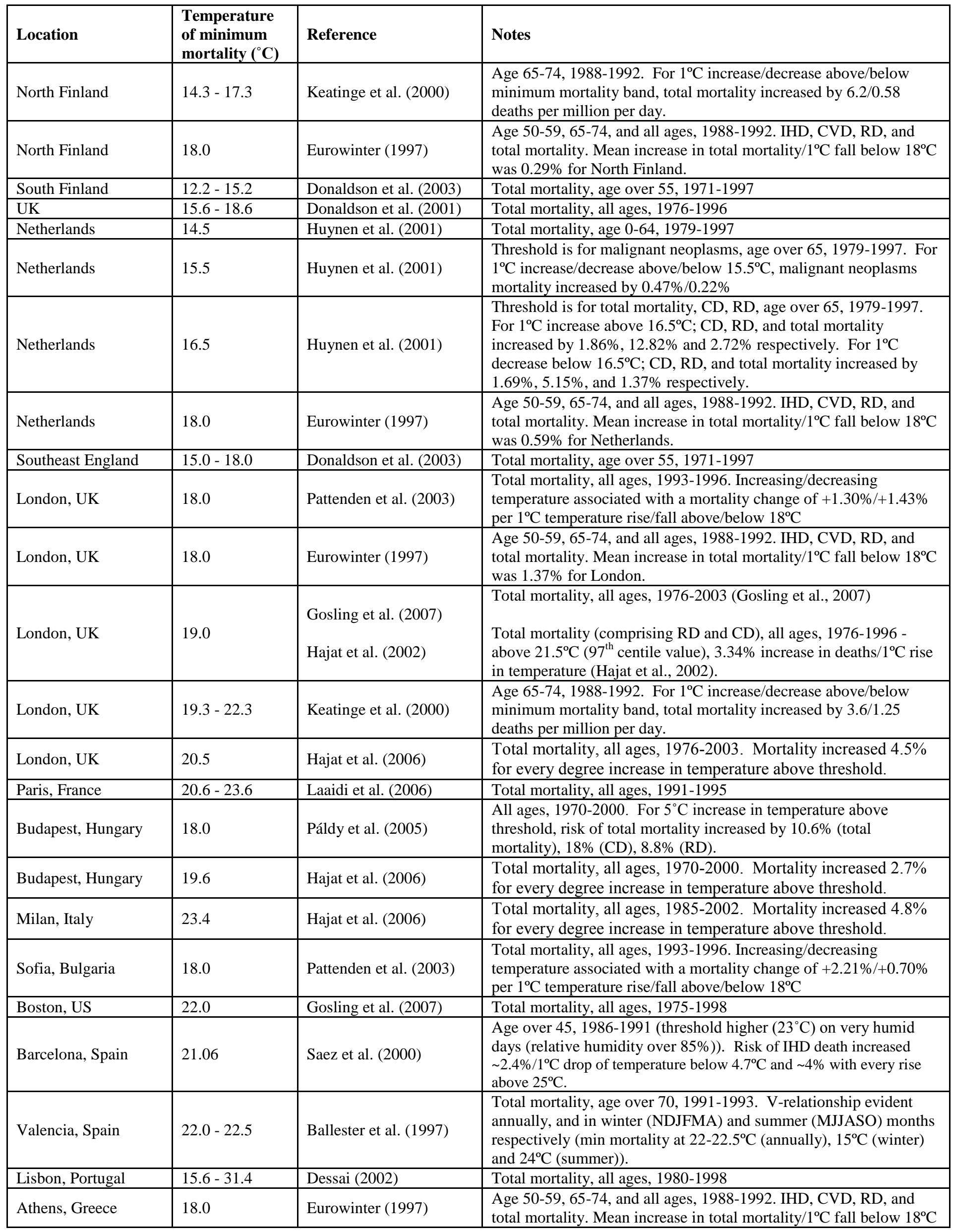




\begin{tabular}{|l|l|l|l|}
\hline & & & was 2.15\% for Athens. \\
\hline Athens, Greece & $22.7-25.7$ & Keatinge et al. (2000) & $\begin{array}{l}\text { Age 65-74, 1988-1992. For } 1^{\circ} \mathrm{C} \text { increase/decrease above/below } \\
\text { minimum mortality band, total mortality increased by } 2.7 / 1.6 \text { deaths } \\
\text { per million per day. }\end{array}$ \\
\hline North Carolina, US & $22.3-25.3$ & Donaldson et al. (2003) & Total mortality, age over 55, 1971-1997 \\
\hline Sydney, Australia & 20.0 & McMichael et al. (2002) & $\begin{array}{l}\text { Total mortality, age over 65, 1997-1999. Deaths increased by } \\
1 \% \text {, each } 1^{\circ} \mathrm{C} \text { above the threshold temperature. }\end{array}$ \\
\hline Sydney, Australia & 26.0 & Gosling et al. (2007) & Total mortality, all ages, 1988-2003 \\
\hline Taiwan & $26.0-29.0$ & Pan et al. (1995) & Coronary heart disease and cerebral infraction in elderly \\
\hline
\end{tabular}

IHD (ischaemic heart disease), CVD (cerebrovascular disease), CD (cardiovascular disease), RD (respiratory disease). 
Table 6 Studies analysing lag effects between extreme temperatures and excess mortality. Lags are for total mortality (unless otherwise stated).

\begin{tabular}{|c|c|c|}
\hline Reference & Study Area & Lags Observed \\
\hline Davis et al. (2003) & 28 US cities & Main heat effects occurred with 1 day lag for all 28 cities. \\
\hline Braga et al. (2001) & 12 US cities & $\begin{array}{l}\text { Main heat effects occurred with } 0 \text { or } 1 \text { day lag and were twice as large } \\
\text { as cold effects. Main cold effects occurred with } 0 \text { day lag, decreasing in } \\
\text { effect up to } 2 \text { weeks depending on city. Inverse heat effects at } 2-4 \text { day } \\
\text { lags (mortality displacement) but not for cold effects. }\end{array}$ \\
\hline Curriero et al. (2002) & 11 cities in Eastern US & $\begin{array}{l}\text { Main cold effects occurred with lags up to } 3 \text { days, and up to } 1 \text { day for } \\
\text { heat effects. }\end{array}$ \\
\hline O’Neill et al. (2003) & 7 US cities & $\begin{array}{l}\text { Main heat effects modelled with } 0 \text { day lag, and cold effects with a mean } \\
\text { of temperatures associated with } 1,2,3 \text { day lags. }\end{array}$ \\
\hline Kalkstein (1991) & St. Louis, US & 1-day lag associated most with TSI-mortality relationship. \\
\hline Whitman et al. (1997) & Chicago, US & Main heat effects occurred with 2 day lag \\
\hline $\begin{array}{l}\text { Donaldson et al. } \\
(2001)\end{array}$ & UK & Main heat effects occurred with 0 day lag. \\
\hline Hajat et al. (2002) & London, UK & $\begin{array}{l}\text { Main heat effects occurred with } 0 \text { day lag, decreasing in effect up to } 3 \\
\text { days. }\end{array}$ \\
\hline Hajat et al. (2006) & $\begin{array}{l}\text { London, UK } \\
\text { Budapest, Hungary } \\
\text { Milan, Italy }\end{array}$ & $\begin{array}{l}\text { Main heat effects occurred with } 0 \text { day lag. Evidence of mortality } \\
\text { displacement in London. }\end{array}$ \\
\hline Keatinge et al. (2000) & $\begin{array}{l}\text { North Finland } \\
\text { London, UK } \\
\text { Athens, Greece }\end{array}$ & Main heat effects analysed with 0 day lag, cold effects with 3 day lag. \\
\hline $\begin{array}{l}\text { Donaldson et al. } \\
(2003)\end{array}$ & $\begin{array}{l}\text { North Carolina, US } \\
\text { South Finland } \\
\text { Southeast England }\end{array}$ & Main heat effects occurred with 0 day lag. \\
\hline Hajat et al. (2005) & $\begin{array}{l}\text { Delhi, India } \\
\text { São Paulo, Brazil } \\
\text { London, UK }\end{array}$ & $\begin{array}{l}\text { Main heat effects occurred with 0- and 1-day lag. } \\
\text { Excess evident up to } 3 \text { weeks after exposure in Delhi, but in London, } \\
\text { excess persisted only } 2 \text { days and followed by deficits (mortality } \\
\text { displacement) - intermediate effects observed for São Paulo. }\end{array}$ \\
\hline Gosling et al. (2007) & $\begin{array}{l}\text { Boston, US } \\
\text { Budapest, Hungary } \\
\text { Dallas, US } \\
\text { Lisbon, Portugal } \\
\text { London, UK } \\
\text { Sydney, Australia } \\
\end{array}$ & $\begin{array}{l}\text { Main heat effects occurred with } 0 \text { day lag. Inverse heat effects evident } \\
\text { beyond 3-day lags (mortality displacement). Mortality displacement } \\
\text { accounted for a higher proportion of deaths in cities with weaker } \\
\text { temperature-mortality relationships (e.g. Dallas) than cities with } \\
\text { stronger relationships (e.g. Boston). }\end{array}$ \\
\hline Pattenden et al. (2003) & $\begin{array}{l}\text { Sofia, Bulgaria } \\
\text { London, UK }\end{array}$ & $\begin{array}{l}\text { Main heat effects occurred with } 0 \text { day lag. Inverse heat effects after } 3 \\
\text { days in Sofia (mortality displacement) but not London. } \\
\text { Main cold effects occurred after } 4 \text { days and decreasing in effect for over } \\
2 \text { weeks. } \\
\text { Inverse cold effects after } 3 \text { weeks in Sofia but not London. }\end{array}$ \\
\hline Páldy et al. (2005) & Budapest, Hungary & Main heat effects occurred with 0-1 day lag \\
\hline Dessai (2002) & Lisbon, Portugal & Main heat effects occurred with 1 day lag. \\
\hline Ballester et al. (1997) & Valencia, Spain & $\begin{array}{l}\text { Main heat effects on total mortality occur with a less than } 7 \text { day lag but } \\
\text { effects on RD had a 7-14 day lag. Cold effects exhibited a positive } \\
\text { effect on mortality up to } 2 \text { months following exposure. }\end{array}$ \\
\hline Conti et al. (2005) & 5 Italian cities & $\begin{array}{l}\text { Main heat effects occurred with lags of } 2 \text { days (Rome), } 3 \text { days (Bari and } \\
\text { Genoa), and } 4 \text { days (Milan and Turin). }\end{array}$ \\
\hline $\begin{array}{l}\text { Michelozzi et al. } \\
(2005)\end{array}$ & $\begin{array}{l}\text { Rome, Italy } \\
\text { Milan, Italy } \\
\text { Turin, Italy }\end{array}$ & Main heat effects occurred with 1-2 day lag. \\
\hline $\begin{array}{l}\text { Vandentorren et al. } \\
(2004)\end{array}$ & 13 French cities & $\begin{array}{l}\text { Main heat effects occurred with 1-3 day lag during the France } 2003 \text { heat } \\
\text { wave }\end{array}$ \\
\hline Sartor et al. (1995) & Belgium & $\begin{array}{l}\text { Main heat effects occurred with } 1 \text { day lag - deficits 11-18 days after heat } \\
\text { wave. }\end{array}$ \\
\hline $\begin{array}{l}\text { Kassomenos et al. } \\
(2007)\end{array}$ & Athens, Greece & $\begin{array}{l}\text { Main association between TSI and mortality occurred with } 0 \text { day lag } \\
\text { during cold months, but persisted longer for warm months. }\end{array}$ \\
\hline Huynen et al. (2001) & Netherlands & $\begin{array}{l}\text { Main heat effects occurred with } 0 \text { day lag, decreasing in effect up to } 6 \\
\text { days, with inverse effects at lags of 7-30 days (mortality displacement). } \\
\text { Main cold effects occurred with 7-14 day lag, with no evidence for } \\
\text { mortality displacement. }\end{array}$ \\
\hline
\end{tabular}

IHD (ischaemic heart disease), CVD (cerebrovascular disease), CD (cardiovascular disease), RD (respiratory disease), MI (myocardial infarction). 
Figure 1. The cascading effects of uncertainty for assessing the impacts of climate change on heat-related mortality. The total uncertainty in the final impact increases as individual uncertainties are combined (not to scale).

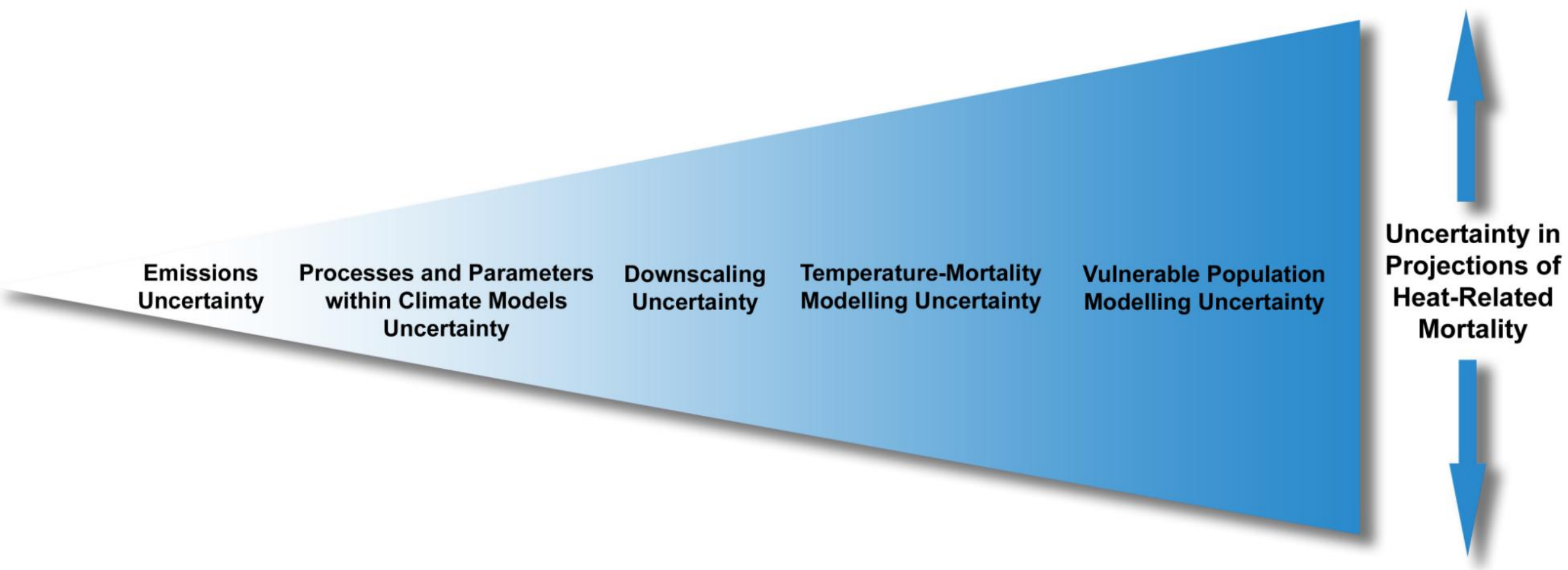


Figure 2. The IPCC Special Report on Emission Scenarios (SRES) produced four families of plausible and equally valid "storylines", or scenarios, which assume different increases in greenhouse gas emissions in the future. Each family is labelled A1, A2, B2 and B1. This set of scenarios consists of six scenario groups drawn from the four families, one group each in A2, B1, B2 (labelled A2, B1 and B2 respectively), and three groups within the A1 family characterizing alternative developments of energy technologies (A1FI (fossil fuel intensive), A1B (balanced; ; not relying too heavily on one particular energy source, on the assumption that similar improvement rates apply to all energy supply and end use technologies), and A1T (predominantly non-fossil fuel)).

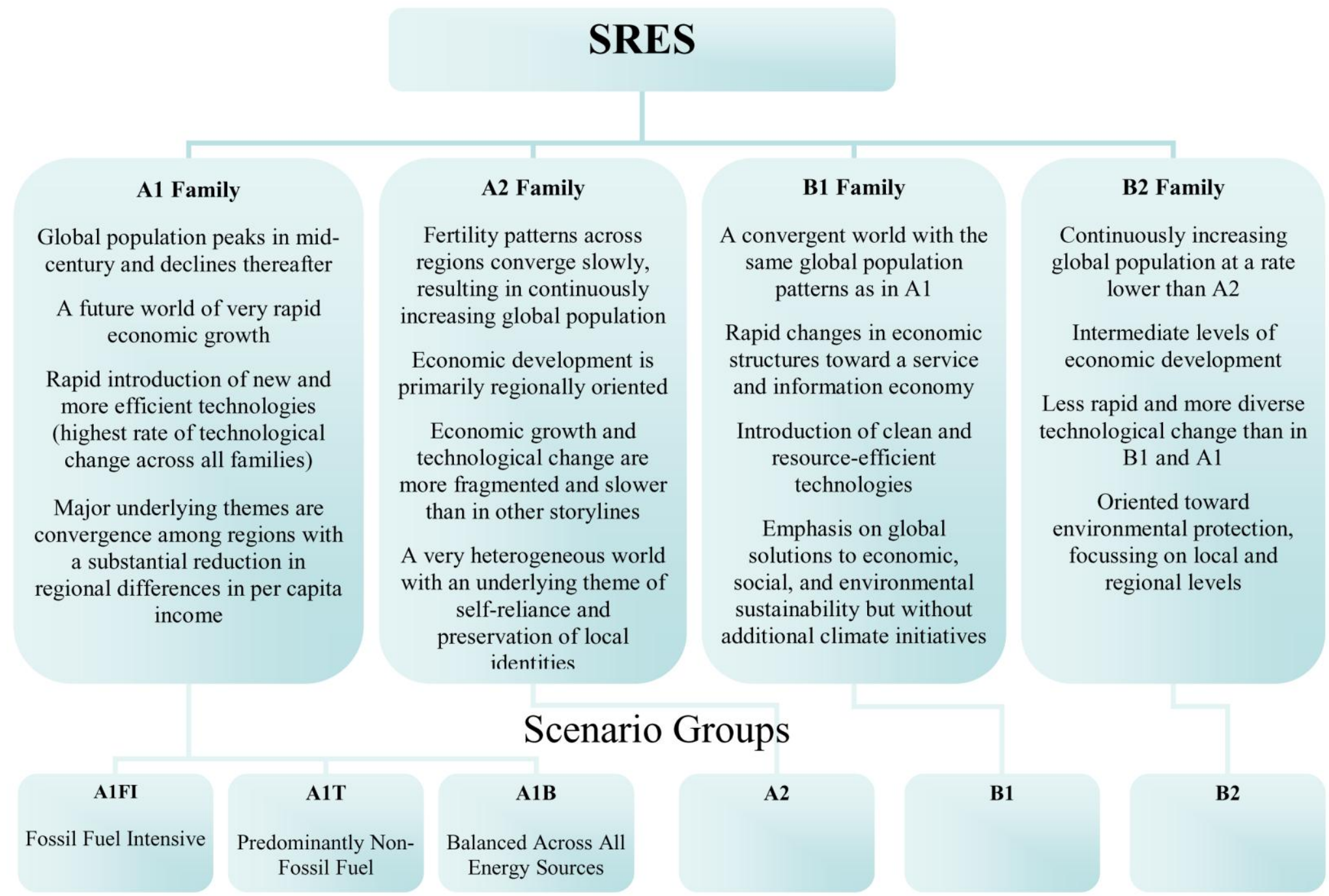

Adapted from Nakićenović and Swart (2000) 
Figure 3. Uncertainties in climate change: (A) emissions uncertainty, (B) large scale climate modelling uncertainty, and (C) downscaling uncertainty. (A) illustrates the simulated mean global temperature rise $\left({ }^{\circ} \mathrm{C}\right)$ relative to present from one climate model (HadCM3) for four SRES emissions scenarios. (B) illustrates the same as (A) but only for the SRES A2 emission scenario and for several climate models. (C) illustrates the average number of days per year (x-axis) in a simulated 1961-1990 period that particular maximum daily temperatures $\left({ }^{\circ} \mathrm{C}\right.$; y-axis) were exceeded for an atmospheric global model (dashed line), and a regional model that was driven by the global model (solid line) for the model grid box that contains London. For example, if the daily maximum temperature was greater than $30^{\circ} \mathrm{C}$ for 120 days during the 30 year period (1961-1990) then $30^{\circ} \mathrm{C}$ would have been exceeded by 4 days per year on average.

\section{(A) Emissions Uncertainty}

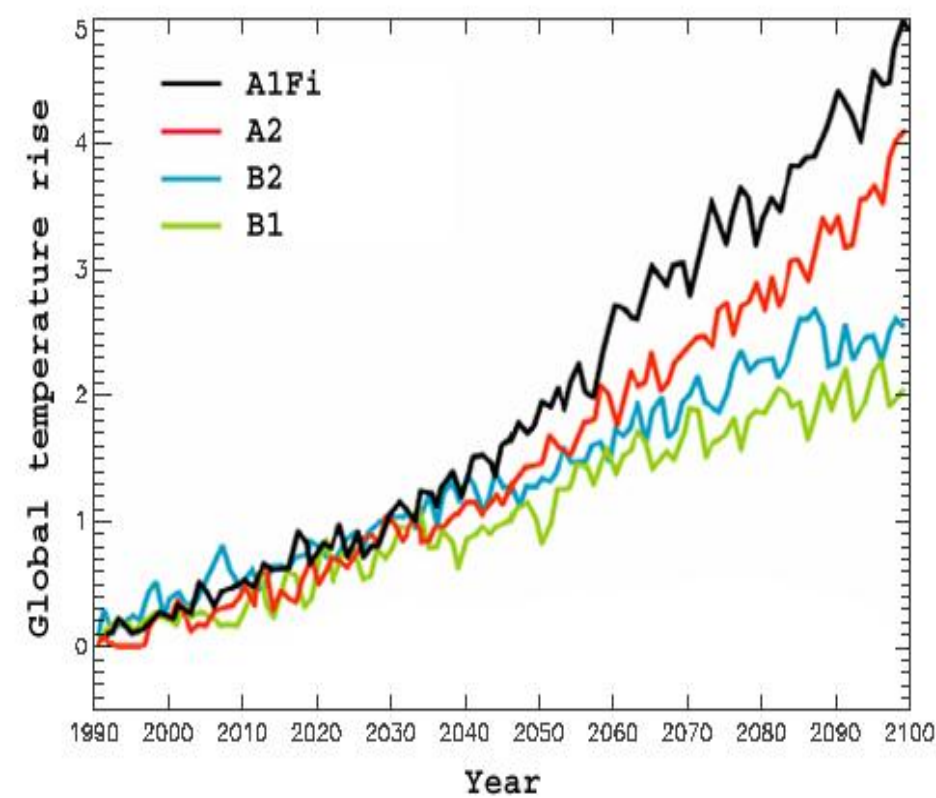

(B) Large Scale Climate Modeling Uncertainty

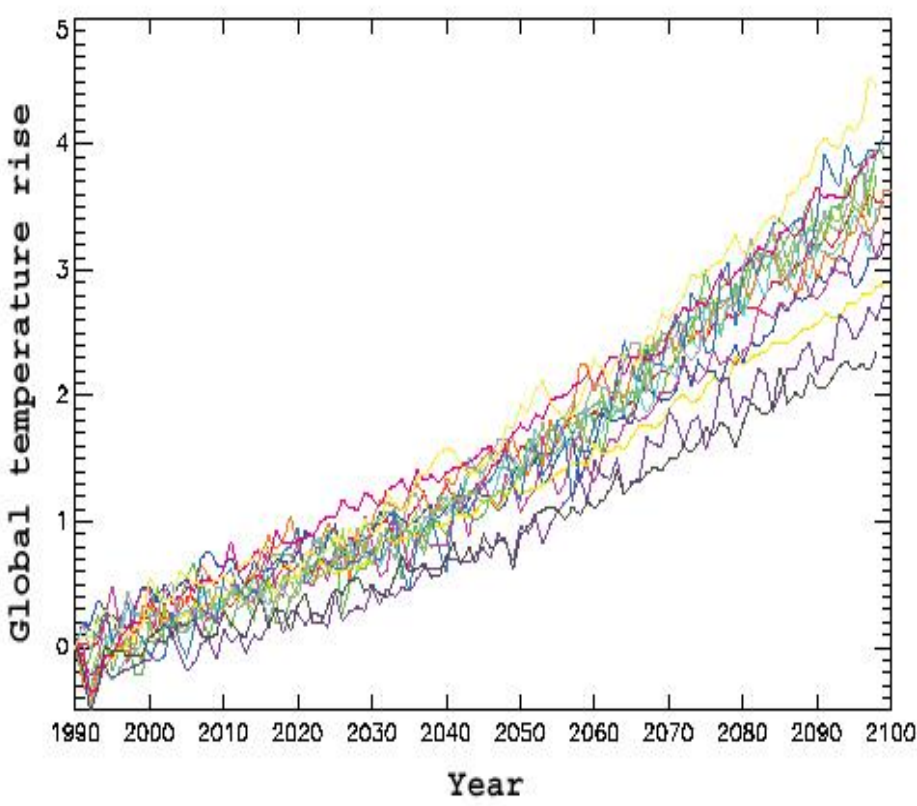

(C) Downscaling Uncertainty

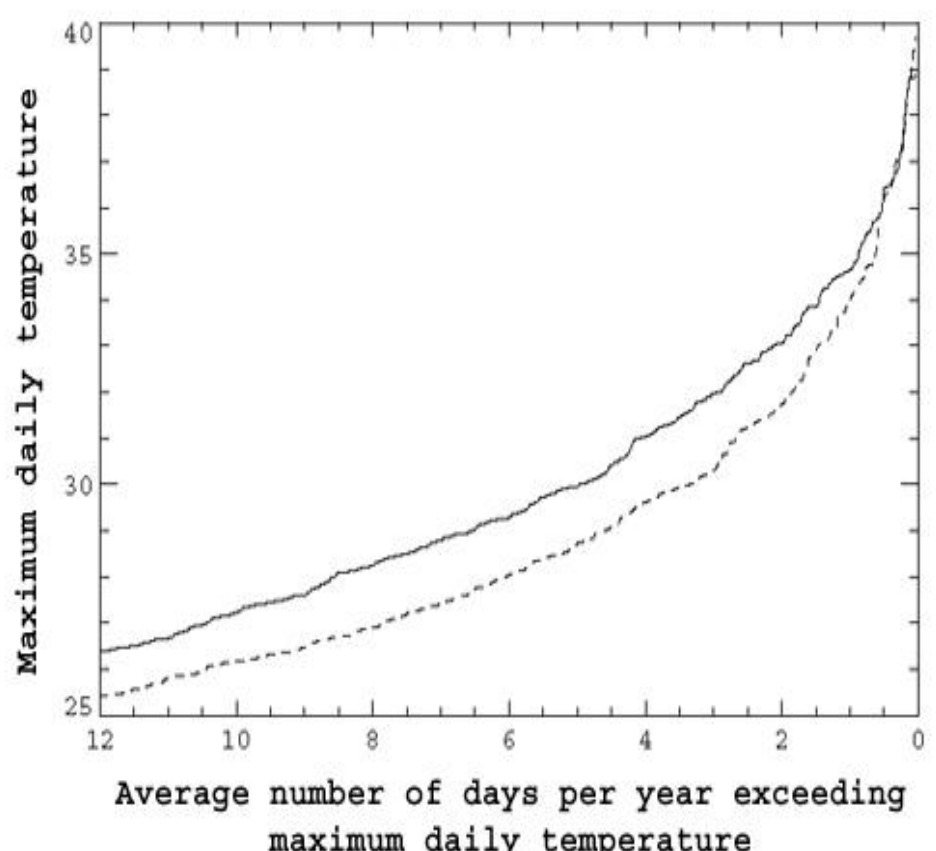

